\title{
Modulating endothelial nitric oxide synthase: a new cardiovascular therapeutic strategy
}

Citation for published version (APA):

Zhang, Y., Janssens, S. P., Wingler, K., Schmidt, H. H. H. W., \& Moens, A. L. (2011). Modulating endothelial nitric oxide synthase: a new cardiovascular therapeutic strategy. American Journal of Physiology-heart and Circulatory Physiology, 301(3), H634-H646.

https://doi.org/10.1152/ajpheart.01315.2010

Document status and date:

Published: 01/09/2011

DOI:

10.1152/ajpheart.01315.2010

Document Version:

Publisher's PDF, also known as Version of record

Document license:

Taverne

Please check the document version of this publication:

- A submitted manuscript is the version of the article upon submission and before peer-review. There can be important differences between the submitted version and the official published version of record.

People interested in the research are advised to contact the author for the final version of the publication, or visit the DOI to the publisher's website.

- The final author version and the galley proof are versions of the publication after peer review.

- The final published version features the final layout of the paper including the volume, issue and page numbers.

Link to publication

\footnotetext{
General rights rights.

- You may freely distribute the URL identifying the publication in the public portal. please follow below link for the End User Agreement:

www.umlib.nl/taverne-license

Take down policy

If you believe that this document breaches copyright please contact us at:

repository@maastrichtuniversity.nl

providing details and we will investigate your claim.
}

Copyright and moral rights for the publications made accessible in the public portal are retained by the authors and/or other copyright owners and it is a condition of accessing publications that users recognise and abide by the legal requirements associated with these

- Users may download and print one copy of any publication from the public portal for the purpose of private study or research.

- You may not further distribute the material or use it for any profit-making activity or commercial gain

If the publication is distributed under the terms of Article $25 \mathrm{fa}$ of the Dutch Copyright Act, indicated by the "Taverne" license above, 


\title{
TRANSLATIONAL PHYSIOLOGY
}

\section{Modulating endothelial nitric oxide synthase: a new cardiovascular therapeutic strategy}

\author{
Yixuan Zhang, ${ }^{1}$ Stefan P. Janssens, ${ }^{3}$ Kirstin Wingler, ${ }^{2}$ Harald H. H. W. Schmidt, ${ }^{2}$ and An L. Moens ${ }^{1}$ \\ Departments of ${ }^{1}$ Cardiology and ${ }^{2}$ Pharmacology, Maastricht University Medical Centre, Cardiovascular Research Institute \\ Maastricht, Maastricht, The Netherlands; and ${ }^{3}$ Department of Cardiology, Catholic University of Leuven, Leuven, Belgium
}

Submitted 3 January 2011; accepted in final form 26 May 2011

\begin{abstract}
Zhang Y, Janssens SP, Wingler K, Schmidt HH, Moens AL. Modulating endothelial nitric oxide synthase: a new cardiovascular therapeutic strategy. Am J Physiol Heart Circ Physiol 301: H634-H646, 2011. First published May 27, 2011; doi:10.1152/ajpheart.01315.2010.- The pathogenesis of many cardiovascular diseases is associated with reduced nitric oxide (NO) bioavailability and/or increased endothelial NO synthase (eNOS)-dependent superoxide formation. These findings support that restoring and conserving adequate NO signaling in the heart and blood vessels is a promising therapeutic intervention. In particular, modulating eNOS, e.g., through increasing the bioavailability of its substrate and cofactors, enhancing its transcription, and interfering with other modulators of eNOS pathway, such as netrin-1, has a high potential for effective treatments of cardiovascular diseases. This review provides an overview of the possibilities for modulating eNOS and how this may be translated to the clinic in addition to describing the genetic models used to study eNOS modulation.
\end{abstract}

endothelial nitric oxide synthase uncoupling; modulators; superoxide; tetrahydrobiopterin; enhancers; nitric oxide donors

THE REVALENCE AND SEVERITY of incipient or overt cardiovascular diseases associated with reduced nitric oxide (NO) bioavailability has resulted in efforts to restore and conserve adequate NO signaling in the heart and blood vessels through therapeutic interventions. In the cardiovascular system, the signaling molecule NO, which is produced by the enzyme endothelial NO synthase (eNOS, NOS3), has a crucial role in maintaining normal vascular function, mediated by its vasodilating capacity and through a variety of antiatherogenic effects. eNOS is not only expressed in endothelial cells of the heart and blood vessels, in both atrial and ventricular myocytes, but also in specialized pacemaker tissue.

Uncoupling of bioactive, i.e., dimeric eNOS to an inactive monomeric form (73) is caused by oxidative stress, which reduces the bioavailability of tetrahydrobiopterin $\left(\mathrm{BH}_{4}\right)$, an essential cofactor of eNOS. In this uncoupled state, NADPH consumption and oxygen reduction are uncoupled from L-arginine oxidation and NO formation with a subsequently decreased NO production and increased superoxide generation (157). eNOS generated superoxide, further oxidizes $\mathrm{BH}_{4}$, and hence enhances the uncoupling of eNOS. However, it is unclear which source of superoxide initiates eNOS uncoupling.

Address for reprint requests and other correspondence: A. L. Moens, Maastricht Univ. Medical Ctr., Cardiovascular Research Inst. Maastricht, P. Delbeyelaan 25, 6202 AZ Maastricht, The Netherlands (e-mail: an.moens @mumc.nl).
Uncoupling of eNOS has been described in 1) situations associated with endothelial dysfunction such as atherosclerosis (3, 70), diabetes mellitus (135), ischemia-reperfusion (I/R) injury $(35,138)$, hypertension $(68)$, and chronic flow overload (78); 2) cardiac hypertrophy with ventricular remodeling (133); and 3) diastolic heart failure (149). eNOS also uncouples physiologically. For example, eNOS may uncouple postnatal in the lung, possibly leading to a developmental adaptation of the pulmonary vascular system to produce reactive oxygen species (ROS) (81). In addition, it has been demonstrated that purified eNOS is never fully coupled (46). eNOS can be modulated by directly or indirectly increasing the bioavailability of its cofactors and substrate, increasing its transcription and interfering with eNOS modulators, such as netrin-1, resulting in increased NO-production and/or less eNOS-dependent generation of free radicals.

In this review, we describe the different possibilities to modulate eNOS (see Fig. 1) and how the modulation of eNOS can be applied as a new therapeutic approach for cardiovascular diseases in which the uncoupling of eNOS has been described to be of pathogenetic importance.

\section{The Role of NOS Substrate: L-Arginine}

The exact mechanism that causes the uncoupling of NO synthase in physiological and pathophysiological conditions is unclear. Lack of both the substrate L-arginine $(114,156)$ and binding of $\mathrm{BH}_{4}$ (157) may be involved. L-Arginine stimulates oxygen uptake by coupled eNOS (46) and prevents superoxide 


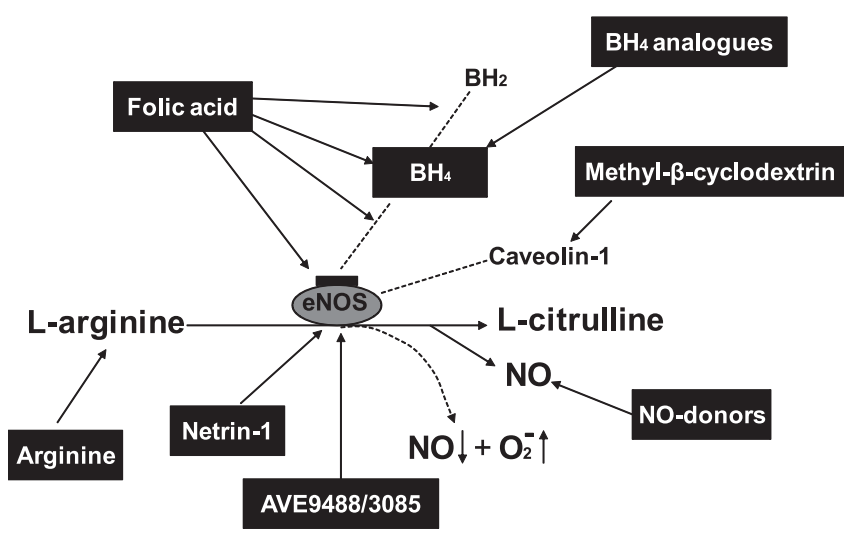

Fig. 1. Schematic overview of the different endothelial nitric oxide (NO) synthase (eNOS) modulators. $\mathrm{BH}_{4}$, tetrahydrobiopterin.

formation within uncoupled eNOS by electronic interaction with the heme-bound oxygen (9). Steady-state L-arginine levels may be increased by either inhibiting L-arginine breakdown via arginase (54) or by supplying additional arginine. The latter approach has been tested in many clinical trials with contrasting results. Short- to medium-term administration of arginine improves NO-mediated vascular function in elderly humans as well as a variety of clinical conditions, including hypercholesterolemia, coronary artery disease, congestive heart failure, and peripheral artery disease (PAD) (13). However, in other trials L-arginine was not beneficial (13) or the benefits did not continue with chronic therapy. Importantly, one study has suggested possible harm in post-myocardial infarction patients treated with oral arginine (117), although the causal relationship between deaths and arginine administration has been questioned. Arginine-based nutritional adjunct to PAD therapy gained support from several short-term clinical studies. Nevertheless, in the Nitric Oxide in Peripheral Arterial Insufficiency Study (NO PAIN I), the largest randomized clinical trial of the longest duration in patients with PAD (151), the longterm administration of arginine ( $3 \mathrm{~g} /$ day) did not increase NO availability, walking distance, or vascular reactivity. Furthermore, the data indicated that long-term administration of Larginine might even impair functional capacity. It was concluded that, as opposed to short-term administration, long-term administration may not be useful in patients with intermittent claudication due to PAD (151).

The exact reasons for the contrasting findings of clinical studies testing L-arginine supplementation are unknown, and it is not entirely clear if and why L-arginine oral administration may work at all. It has been suggested that prolonged L-arginine supplementation results in "arginine tolerance," possibly involving the induction of arginases. Furthermore, oral arginine supplementation has low bioavailability: approximately $40 \%$ of dietary L-arginine is catabolized in the intestine, a further fraction is metabolized by liver arginase to urea, and only $1 \%$ of oral arginine becomes available as a substrate for NOS (14). Importantly, intracellular L-arginine levels may never decrease to the subsaturating levels for eNOS, even under nonpathophysiological conditions (28), and L-arginine is intracellular regenerated (124). The $K_{\mathrm{m}}$ for L-arginine as a substrate for eNOS is $2-15 \mu \mathrm{M}$, and the cytoplasmic level of arginine is 600 to $900 \mu \mathrm{M}$. Thus arginine should not become limiting for NO formation at all. However, asymmetric dime-
thyl-L-arginine (ADMA), an endogenous competitive eNOS inhibitor that acts at the eNOS substrate binding site, is increased under pathophysiological conditions (20). It not only directly inhibits eNOS but also inhibits endothelial L-arginine uptake via cationic amino acid transporters (4). In vitro, ADMA uncouples eNOS and elevates ROS generation in the absence of $\mathrm{BH}_{4}$ but not in the presence of L-arginine (34). Moreover, basal and stimulated NO release appear to be affected differently by ADMA (2).

Irrespective of the underlying beneficial mechanism of Larginine supplementation, L-arginine supplementation may sometimes be ineffective and even harmful. In rat hyperoxaluric kidneys and excessive crystal deposition, for example, L-arginine administration increases oxidative and nitrosative stress in an $N^{\omega}$-nitro-L-arginine methyl ester (L-NAME) reversible manner (54). Thus the supplementation of L-arginine is not a promising strategy to treat cardiovascular diseases.

\section{The Role of $\mathrm{NOS}$ Cofactor $\mathrm{BH}_{4}$}

$\mathrm{BH}_{4}$ has been recognized as an essential cofactor of eNOS since it was first described in 1989 (134). In its coupled state, $\mathrm{BH}_{4}$ is tightly bound to eNOS, and the amount of binding is correlated with eNOS activity (7). In the presence of its substrates (L-arginine and oxygen), eNOS catalyzes the formation of L-citrulline and NO. In the presence of subsaturating levels of $\mathrm{BH}_{4}$, the electron transfer in eNOS becomes uncoupled from L-arginine oxidation and NO formation. This uncoupling results in superoxide production by eNOS. When the bioavailability of $\mathrm{BH}_{4}$ or L-arginine declines, the eNOS dimer demonstrates a less tightly packed oxidase domain and a higher sensitivity to proteolysis (103). Multiple pleiotropic roles of $\mathrm{BH}_{4}$ in eNOS enzymatic function have been demonstrated: $\mathrm{BH}_{4}$ 1) facilitates the binding of L-arginine substrate to eNOS, 2) shifts the heme iron into a high spin state that increases enzyme activity, 3) is involved in electron transfer, and 4) stabilizes the NOS dimer $(24,63,65,108)$. Stoll et al. (128) demonstrated that eNOS also stabilizes $\mathrm{BH}_{4}$ by controlling its protonation state. $\mathrm{BH}_{4}$ itself has also direct intrinsic antioxidant effects (90). Furthermore, Landmesser et al. (68) provided evidence that eNOS uncoupling contributes to systemic hypertension in the DOCA-salt rat model of hypertension. In addition, the prevention of pressure overload-induced eNOS uncoupling by $\mathrm{BH}_{4}$ suggested a potential therapeutic option of this molecule for chronic pressure overload-induced ventricular remodeling (133). It has also been shown that an overexpression of eNOS cannot rescue atherosclerotic lesion in apolipoprotein E-knockout $\left(\mathrm{ApoE}^{-/-}\right.$) mice, but a simultaneous supplementation of $\mathrm{BH}_{4}$ or an upregulation of the rate-limiting enzyme of $\mathrm{BH}_{4}$ synthesis, guanosine triphosphate cyclohydrolase-1 (GTPCH-1), led to a recovery of eNOS bioactivity (i.e., eNOS recoupling), thereby improving endothelial function and reducing disease progression (102). Although eNOS expression was increased, NO release was not reversed without correspondingly increasing of $\mathrm{BH}_{4}$ in a spontaneously prehypertensive rat model (27). The administration of L-arginine to bEnd. 3 cells, without an administration of additional $\mathrm{BH}_{4}$, exacerbated ROS generation caused by indicating that eNOS uncoupling induced ROS generation because of relative $\mathrm{BH}_{4}$ deficiency (11). In vivo investigation of eNOS regulation clearly indicates a very tight stochiometric relation between 
eNOS and $\mathrm{BH}_{4}$ to achieve an optimal eNOS coupling status (7). Once generated, superoxide reacts with $\mathrm{NO}$ to form the highly reactive intermediate peroxynitrite. $\mathrm{BH}_{4}$ is unstable at $\mathrm{pH} 7.4$ and is oxidized rapidly by low concentrations of peroxynitrite (87). An increased formation of peroxynitrite in turn oxidizes $\mathrm{BH}_{4}$ to the $\mathrm{BH}_{3}$ radical. In addition, the oxidized form $\mathrm{BH}_{2}$ may compete with $\mathrm{BH}_{4}$ for binding at eNOS with subsequently further exacerbated eNOS uncoupling (145). However, the increased expression of GTPCH-1 can prevent the decrease in $\mathrm{BH}_{4}$ levels in isolated cells and in atherosclerotic animal models (162). Aoki et al. (6) showed in human umbilical vein endothelial cells that fluvastatin, a 3-hydroxy3-methyl-glutaryl-CoA reductase inhibitor, not only upregulated eNOS activity via enhancement of its phosphorylation at $\operatorname{Ser}^{1177}$ and $\operatorname{Ser}^{633}$ but also prevented eNOS uncoupling via elevating $\mathrm{BH}_{4}$ levels through enhancing GTPCH expression.

Recently, it has been reported that thiol-specific reducing agents can restore impaired endothelium-dependent vasodilation caused by $S$-glutathionylation of eNOS as an alternative of $\mathrm{BH}_{4}$ repletion for the recoupling of eNOS (22).

Because of the major pathogenic role of $\mathrm{BH}_{4}$ deficiency in the onset of cardiovascular diseases, $\mathrm{BH}_{4}$ supplementation has been explored as a new therapeutic strategy in many experimental models. It has been demonstrated that $\mathrm{BH}_{4}$ improves $\mathrm{I} / \mathrm{R}$ injury in isolated perfused rat hearts $(35,160)$. In $\mathrm{ApoE}^{-1-}$ mice, $\mathrm{BH}_{4}$ supplementation reduces vascular immune cell infiltration in atherosclerosis through maintaining eNOS coupling and NO bioavailability, thus preventing the progression of atherosclerosis (115). In addition, exogenous $\mathrm{BH}_{4}$ given to mice can recouple an already uncoupled eNOS with a subsequent reversing of pressure overload-induced cardiac hypertrophy, fibrosis, and myocardial dysfunction (91). Recent in vitro data demonstrated that the bioavailability of $\mathrm{BH}_{4}$ is reduced in the early postradiation phase. Berbee et al. (8) demonstrated that the administration of $\mathrm{BH}_{4}$ decreases radiation-induced vascular peroxynitrite production and that the administration of $\gamma$-tocotrienol (GT3, a radioprotective vitamin E analog) 1) reduces the expression of GTPCH feedback regulatory protein, a key negative regulator of $\mathrm{BH}_{4}$ synthesis, and 2) reverses radiation-induced $\mathrm{BH}_{4}$-dependent eNOS uncoupling.

However, it is not easy to determine $\mathrm{BH}_{4}$ deficiency in vivo as plasma concentrations of $\mathrm{BH}_{4}$ do not always provide a reliable indicator of tissue levels or bioavailability (147). A more useful marker may be the ratio of reduced to oxidized biopterins $\left(\mathrm{BH}_{4}: \mathrm{BH}_{2}\right.$ ratio) in cells (145).

Another limiting factor of the potential clinical use of $\mathrm{BH}_{4}$ as a pharmaceutical drug is its chemical instability. $\mathrm{BH}_{4}$ is hydroscopic and easily oxidized to $7,8-\mathrm{BH}_{2}$, and must be frozen for storage. However, $6 \mathrm{R}-\mathrm{BH}_{4}$ is a novel thermo- and photostable $\mathrm{BH}_{4}$ derivate that is commercially available for use as a phenylketonuria drug (Kuvan, Biomarin, San Francisco, CA). Most recently, 6-hydroxymethyl pterin and 6-acetyl-7,7dimethyl-7,8-dihydropterin (ADDP), two oxidatively stable analogs of $\mathrm{BH}_{4}$ that may substitute for $\mathrm{BH}_{4}$ when the pterin site is unoccupied, were demonstrated to have a protective role in limiting endothelial dysfunction in the pulmonary vasculature (66). ADDP is a stable compound that is soluble in both polar and organic solvents. Also, the administration of sepiapterin, a $\mathrm{BH}_{4}$ precursor, together with $\mathrm{N}$-acetylcysteine, has been linked to the correction of vasomotor tone in the vasculature of atherosclerotic rabbits by raising $\mathrm{BH}_{4}$ levels $(144,145)$. Fur- thermore, ascorbic acid (vitamin $\mathrm{C}$ ) has been known to recycle the $\mathrm{BH}_{3}$ radical to $\mathrm{BH}_{4}(67)$ and to prevent oxidation of $\mathrm{BH}_{4}$ (52), thus chemically stabilizing $\mathrm{BH}_{4}$ and enhancing eNOS coupling. There is also in vivo evidence that ascorbate supplements preserved vascular $\mathrm{BH}_{4}$ levels and eNOS activity in atherosclerotic mice (31).

With the development of the synthetic $\mathrm{BH}_{4}$ analog (6R$\mathrm{BH}_{4}$ ), which is already approved by the Food and Drug Administration for the treatment of phenylketonuria, larger trials (unpublished) were set up to study its effect on arterial (NCT00325962, concluded 2008) and pulmonary hypertension (NCT00435331, recruitment stopped in 4/09, no data reported), endothelial dysfunction (NCT00532844, study completed, data unpublished), PAD (NCT00403494, competed 1/09), and sickle cell disease (NCT00445978, completed 6/09). Unfortunately, the overall results were disappointing, not because of adverse effects but because of lacking efficacy, which can be explained in several ways. First, the $K_{\mathrm{m}}$ of $\mathrm{BH}_{4}$ for eNOS is $80 \mathrm{nM}$. If the stoichiometry with NOS isoforms has to be just right, too much of this synthetic $\mathrm{BH}_{4}$ analog might activate constitutive NOS [inducible NOS (iNOS, NOS2)]. Also, the intracellular transport of $\mathrm{BH}_{4}$ is not completely understood. In addition, oral $\mathrm{BH}_{4}$ may be oxidized and must be re-reduced, so this biochemistry becomes very important for the net result. It has been demonstrated that $\mathrm{BH}_{2}$ can be more efficiently transported into cells over $\mathrm{BH}_{4}$, but must then be recycled back to $\mathrm{BH}_{4}$ (51). Recently, Suckling et al. (129) revealed that a novel $\mathrm{BH}_{4}$ analog ADDP can diffuse from the plasma across cell membranes and cause vasodilatation by stimulating eNOS activity. This may provide another avenue for clinical translation.

The biochemistry, molecular biology, and experimental translational evidence support an important role of $\mathrm{BH}_{4}$ as an eNOS modulator to treat myocardial and endothelial dysfunction by stabilizing NOS function and limiting NOS-derived ROS release $(29,30,62,91)$. However, the instability of $\mathrm{BH}_{4}$ remains a point of concern for the translatability of $\mathrm{BH}_{4}$ supplementation for clinical disease. Given the many challenging results that have been reported, one would hope that efforts to further enhance the stability of this interesting molecule will continue and some ultimate translation potential be realized.

\section{The Role of Folic Acid for NO Availability}

The B-vitamin folic acid (FA) plays an important role in the pathogenesis of different developmental abnormalities, particularly neural tube defects (32), neuropathies (104), neuropsychiatric disorders (127), and the development of neoplasms and preneoplastic conditions (155). FA is chemically stable and considered to be safe (92). As folate is an essential vitamin, humans rely on external sources, i.e., food-derived folates or supplementated FA, to fulfill their needs. The absolute minimal requirement of folate to avoid acute deficiency is at least 50 $\mu \mathrm{g} /$ day (126). It is recommended that women consume $600 \mathrm{mg}$ FA per day during pregnancy to prevent brain and spinal cord birth defects (57).

Importantly, folate deficiency has been associated with cardiovascular diseases $(70,92,137)$. The most well-known biological function of FA is its homocysteine-lowering effect mediated by the FA-dependent remethylation of homocysteine to methionine (126). FA also has direct and indirect antioxidant 
effects $(36,53,146)$ and can either directly interact with eNOS or indirectly by restoring the bioavailability of $\mathrm{BH}_{4}$ (56). 5-Methyltetrahydrofolate (5-MTHF), the active metabolite of $\mathrm{FA}$, has a similar structure as that of $\mathrm{BH}_{4}$. Dihydrofolate reductase is involved in the reduction of oxidized $\mathrm{BH}_{2}$ back to $\mathrm{BH}_{4}$, whereas dihydropteridine reductase converts quinonoid$\mathrm{BH}_{2}$ to $\mathrm{BH}_{4}$.

In addition, 5-MTHF can chemically stabilize $\mathrm{BH}_{4}$ and ameliorate the binding affinity of $\mathrm{BH}_{4}$ to eNOS (92). A pteridine-binding domain in eNOS with similarities to the folate binding site of dihydrofolate reductase can serve as a locus through which 5-MTHF can directly bind to eNOS and facilitate the electron transfer by $\mathrm{BH}_{4}$ from the reductase domain of eNOS to its heme $(56,76)$.

Clinically, FA and 5-MTHF have been shown to restore endothelial function in patients with hypercholesterolemia (146), diabetes mellitus (142), hyperhomocysteinemia (153), and atheroscherosis (5). In animals, FA has been demonstrated to significantly improve myocardial function after myocardial infarction in rats (106) and to reduce myocardial ischemic dysfunction and postreperfusion injury in mice (89). However, recent clinical trials have failed to demonstrate a benefit of long-term use of FA $(15,75)$ that can be explained by too low of a dosage (89).

In summary, efforts should be made to further understand the mechanism of FA in preventing and/or reversing both endothelial and myocardial dysfunction and how this can be translated to the clinic.

\section{NO Donors}

Traditional NO donors are predrugs, which rely on the generation of NO for their pharmacological activities. However, there are structurally dissimilar NO donors with different chemical reactivities and metabolic characteristics. More recently, novel signaling molecules, including nitrite $\left(\mathrm{NO}_{2}^{-}\right)$ anions; alternative NO delivery strategies, such as NO gas for inhalation; or hybrid NOS gene and progenitor cell transfer approaches showed promising results in preclinical testing and are gradually introduced in clinical trials $(61,86,100,148)$.

Nitrates, together with the organic nitrites and ferrous nitro complexes including sodium nitroprusside, are generally referred to as nitrovasodilators and exert their biological effects via the release of NO or a related $S$-nitrosothiol. The precise mechanism of organic nitrate bioactivation is incompletely understood but is thought to involve both enzymatic and nonenzymatic mechanisms. The active metabolites following enzymatic reduction by glutathione $S$-transferases (69), cytochrome $P-450$ reductases (1), xanthine oxidoreductases (XORs) (79), and mitochondrial aldehyde dehydrogenases (ALDH-2) (23), in turn, activate the intracellular NO receptor enzyme soluble guanylate cyclase in the vessel wall. Activated soluble guanylate cyclase increases tissue levels of the second-messenger cGMP, which ultimately mediates vasorelaxation via a cGMP-dependent protein kinase.

Organic nitrates have been introduced for over a century in cardiovascular therapy, and compounds such as nitroglycerin, isosorbide di- and mononitrate, and pentaerithrityl tetranitrate are still widely used in the symptomatic treatment of acute coronary syndromes, chronic angina pectoris, and congestive heart failure. The mechanism of action in these drugs is traditionally believed to result from their arterial vasodilation and venodilation effects and improvement of collateral blood flow, resulting in decreased myocardial oxygen consumption and reduced cardiac workload (98). Recently, it has been recognized that these drugs also have intrinsic antiplatelet and antithrombotic effects, demonstrated both in vitro and in vivo, which adds further rationale for their use in atherothrombotic diseases. However, clinical trials have yielded conflicting results regarding clinical outcome, especially with long-term nitrate use (58).

The major limitation, which renders many organic nitrates unsuitable for long-term therapy, is the induction of tolerance and cross-tolerance, characterized by a decreased sensitivity of the vessel wall to the vasorelaxant effect of organic nitrates and to other endothelium-dependent vasodilators or endogenous NO, respectively (50). The molecular target of organic nitrates, i.e., the NO-cGMP signal transduction, cascades itself in the vessel wall and is often impaired by ROS formation, resulting from the activation and upregulation of vascular NADPH oxidases and XORs (64).

Recently, several novel compounds have been synthesized that are devoid of oxidant-generating properties, including $S$-nitrosothiols, nitrovasodilator hybrids containing antioxidant moieties, aminoalkyl and aminoethyl nitrates, and diazeniumdiolate NONOates, which may offer a more optimal therapeutic index and could prove useful in avoiding tolerance, suppressing oxidative stress in atherosclerosis, potentiating antiplatelet effects, and improving clinical outcome (111). The potential mechanisms for the purported benefit involve the activation of endogenous protective pathways, including heme oxygenase-1, and ferritin, the suppression of NADPH oxidase-dependent oxidative stress (119), or compoundspecific ALDH-2- and cytochrome $P$-450-independent pathways (116). Some of these new compounds, harboring an antioxidant moiety in their drug structure, are already being tested in phase II clinical trials of chronic ischemic cardiovascular disorders for their reduced tendency toward tolerance sensitivity (40). Nevertheless, future large-scale clinical trials need to provide the necessary evidence base before widespread clinical introduction.

Circulating $\mathrm{NO}_{2}^{-}$is the largest physiological reservoir of $\mathrm{NO}$ in the body and was long considered as an index of NOS activity, with as much as $70 \%$ of plasma $\mathrm{NO}_{2}^{-}$originating from eNOS. Exogenous sources, principally environmental pollutants and intake of vegetables, also contribute to this NO reserve. While the anion $\mathrm{NO}_{2}^{-}$has traditionally been considered a mere oxidative breakdown product of $\mathrm{NO}$ and a diagnostic marker of its formation at nanomolar concentrations in biological systems, more recent discoveries indicate that $\mathrm{NO}_{2}^{-}$ represents a physiologically relevant storage reservoir of $\mathrm{NO}$ in blood and tissues with distinct signaling functions at nearphysiological concentrations (19). The $\mathrm{NO}_{2}^{-}$anion can be readily reduced to bioactive $\mathrm{NO}$ along a physiological oxygen and $\mathrm{pH}$ gradient either nonenzymatically (167) or by a number of enzymes, including XORs, NOS, mitochondrial cytochromes, and deoxygenated hemoglobin and myoglobin (25, $71,72,122,140)$. $\mathrm{NO}_{2}^{-}$reduction to $\mathrm{NO}$ is enhanced under hypoxic conditions, which serves well its potential as a fast and potent pulmonary and systemic vasodilator drug and as a cytoprotective agent in I/R injury (166). The theoretical ease of the administration of $\mathrm{NO}_{2}^{-}$anions makes it a potentially inter- 
esting drug candidate when NO bioavailability is low. However, the major concern of such a strategy remains the potential risk of inadvertent systemic vasodilation and hypotension caused by circulating $\mathrm{NO}_{2}^{-}$reductases. Currently, there are several clinical studies underway to investigate safety, i.e., methemoglobin formation and inadvertent hypotension, and potential therapeutic efficacy of $\mathrm{NO}_{2}^{-}$administration in patients with acute myocardial infarction, cerebral vasospasm, and pulmonary hypertension (19). When $\mathrm{NO}_{2}^{-}$is administered during noninflammatory states, one of the mechanisms thought to mediate the beneficial effects is that nitrites are stored in erytrocytes and can be secondarily reduced to vasoactive NO by, e.g., XORs under anaerobic conditions (10). Although $\mathrm{NO}_{2}^{-}$has been proposed as a therapy to increase NO production via heme-containing enzymes, the administration of $\mathrm{NO}_{2}^{-}$ in chronic inflammatory disease or infection states needs to be avoided. Because under these conditions, myeloperoxidase can react with $\mathrm{NO}_{2}^{-}$to form nitrogen dioxide radical, which are injurious (18).

The prominent function of circulating NO species and transport of bioactivity in some way from the lungs to the periphery is further supported by a variety of animal and human studies using $\mathrm{NO}$ gas for inhalation $(74,96)$. In concert, these investigations have clearly shown that breathing $\mathrm{NO}$ gas (up to 80 parts/million) for variable periods of time has not only prominent and selective pulmonary vasodilator effects but also detectable systemic effects in remote vascular beds. The latter includes an increase in organ blood flow, an inhibition of coronary platelet-mediated thrombosis, and a marked protection against regional I/R injury. Importantly, none of the above effects was accompanied by prohibitive systemic hypotension.

The mechanisms responsible for these remote effects are likely multiple and include the modification of circulating cells (including leukocytes and platelets) as they pass through the lungs, inhibiting their ability to elicit I/R injury, a reaction with superoxide to form peroxynitrite, which in turn may have dose-dependent cardioprotective effects against I/R (99) or formation of $S$-nitrosothiols or NO-heme complexes in plasma proteins or in circulating cells with regeneration of $\mathrm{NO}$ in systemic vascular beds. $S$-nitrosylation of proteins, a posttranslational modification process that is redox dependent, thiol based, and reversible is a principal mechanism of NO-based signal transduction in cardiovascular biology and involves the attachment of NO moieties to protein sulfydryl groups. Indeed, $S$-nitrosylation of eNOS protein has been recently recognized as another level of dynamic posttranslational control of eNOS activity. eNOS is tonically $S$-nitrosylated at cysteine residues in resting endothelial cells, resulting in a decreased eNOS activity (37). In response to eNOS agonists, eNOS undergoes a rapid transient denitrosylation. Protein nitrosylation is dynamically regulated during physiological and pathophysiological conditions and affects $G$ protein-coupled receptor signaling, mitochondrial metabolic regulation, intracellular calcium handling, and cellular defense against death receptor-mediated apoptosis and oxidative stress in cardiac and vascular cells. The $S$-nitrosylation mechanism is thought to confer much of the benefit of NO-donor compounds in cardioprotection (132), and its role in NO inhalation protocols remains to be specified. At this early stage, the intricate relations between spermine NONOate, cell death, and cardioprotection are still unclear, and $S$-nitrosylation of distinct proteins may result in either cytotoxic or cytopro- tective phenotypes, depending on the circumstances, subcellular compartmentalization, and cross talk with redox and phosphorylation pathways. Finally, inhaled NO may be converted to $\mathrm{NO}_{2}^{-}$, likely through a type of plasma $\mathrm{NO}$ oxidase such as ceruloplasmin (123). $\mathrm{NO}_{2}^{-}$may in turn be converted back to $\mathrm{NO}$ in an acidic/hypoxic environment present in reperfused myocardium by xanthine oxidase (139) or deoxyhemoglobin (26). Alternatively, it may protect myocardium from I/Rinduced injury via NO-independent signaling (17).

In summary, one of the major challenges of almost all NO-donor compounds is the rate of NO delivery and the amount of site-specific generated NO, which are critical determinants of cellular effects. The very short half-life of NO and its dose-dependent cellular activity profile remain a formidable challenge with respect to harnessing its full therapeutic potential.

\section{Transcription Enhancers of eNOS}

4-Fluoro- $N$-indan-2-yl-benzamide (AVE9488, CAS no. 291756-32-6; empirical formula, C16H14FNO) and 2,2difluoro-benzo[1, 3]dioxole-5-carboxylic acid indan-2-ylamide (AVE3085, CAS no. 450348-85-3; empirical formula, C17H13F2NO3) have been described (152) as two novel transcription enhancers of eNOS. These two small molecular-weight pharmacological compounds can increase eNOS protein expression and concomitantly maintain eNOS coupling in different cell in vitro and in vivo models. Accordingly, AVE9488 stimulated eNOS promoter activity in a concentration-dependent manner in human endothelial EA.hy 926 cells in vitro, but without changing eNOS mRNA stability (152).

In a rat model of myocardial infarction-induced heart failure, long-term treatment ( $9 \mathrm{wk}$ ) with AVE9488, by upregulating the expression of eNOS, improved left ventricular (LV) remodeling and myocardial dysfunction. Moreover, AVE9488 increased the levels of circulating endothelial progenitor cell levels in rats with myocardial infarction-induced heart failure (41). In primary human umbilical vein endothelial cells, treatment of AVE9488 showed both an increased eNOS mRNA and protein expression as well as an enhanced bradykinin-stimulated release of $\mathrm{NO}$ (152). Following these initial observations in cell culture conditions, AVE9488 has been shown to improve eNOS expression levels and confer cardiovascular protective effects in different transgenic animal models. For example, subchronic treatment (17 days) with AVE9488 (30 $\mathrm{mg} \cdot \mathrm{kg}^{-1} \cdot \mathrm{day}^{-1}$ ) once a day in adult C57BL/6J mice and a lower dose $\left(10 \mathrm{mg} / \mathrm{kg}\right.$ twice daily) in $\mathrm{ApoE}^{-/-}$mice significantly increased eNOS protein levels in femoral arteries and in aortas, respectively. Interestingly, AVE9488-treated $\mathrm{ApoE}^{-/-}$ mice demonstrated reduced cuff-induced neointima formation. Moreover, this eNOS-mediated inhibiting effect on vascular neointima formation was confirmed using $\mathrm{eNOS}^{-1-}$ mice. A 12-wk-long-term treatment with AVE9488 reduced the area of atherosclerotic plaque in $\mathrm{ApoE}^{-/-}$mice, but not in $\mathrm{ApoE} /$ eNOS-double knockout mice, whereas it did not change plasma lipid levels or heart rate in either animal strain. More importantly, aortas from $\mathrm{ApoE}^{-1-}$ mice, which were treated with AVE9488 $\left(30 \mathrm{mg} \cdot \mathrm{kg}^{-1} \cdot \mathrm{day}^{-1}\right)$ for $2 \mathrm{wk}$ showed enhanced vascular $\mathrm{BH}_{4}$ levels. The administration of L-NAME could not 
further reduce ROS production in aortic rings, indicating that AVE9488 reversed eNOS uncoupling $(70,152)$.

Sasaki et al. (110) demonstrated that pretreatment of AVE9488 can at least in part restore the impaired neovascularization capacity of endothelial progenitor cells from patients with ischemic cardiomyopathy. The enhanced mRNA expression and activity of eNOS was associated with an improved migratory capacity in vitro, which specifically involved NO and improved neovascularization capacity of the infused bone marrow mononuclear cells in an ischemic hindlimb model. Furthermore, it has been demonstrated that AVE9488 has a protective role in cardiac in vivo $\mathrm{I} / \mathrm{R}$ injury by upregulating eNOS expression and thereby increasing NO production and reducing ROS in mice (43). In addition, AVE9488 reduced platelet activation in parallel to positive modulation of systemic NO bioavailability in rats with severe congestive heart failure (112). A different 12-wk treatment with AVE3085, another eNOS transcription enhancer, reduced atherosclerotic plaque formation in ApoE ${ }^{-1-}$ mice, but not in ApoE/eNOSdouble knockout mice as shown with AVE9488 (152). Xue et al. (158) demonstrated that AVE3085 protects against I/R injury in porcine coronary small arteries endothelium through directly enhancing eNOS expression in vitro. In spontaneously hypertensive rats, AVE3085 can improve endothelial function by its acute and chronic transcriptional enhancement of eNOS (159). Chronic treatment for 4 wk with AVE3085 significantly reduced blood pressure. In vitro, it markedly increased acetylcholine-induced relaxation as observed in the acute group (rat aortas treated with $2 \mathrm{~h}$ AVE3085). eNOS and phosphorylated eNOS protein levels were significantly higher in AVE3085treated spontaneously hypertensive rats compared with nontreated groups. Although a 48-day chronic treatment with AVE3085 (10 $\left.\mathrm{mg} \cdot \mathrm{kg}^{-1} \cdot \mathrm{day}^{-1}\right)$ in male diabetic Sprague-Dawley rats did not alter arterial blood pressure or severe hyperglycaemia, it significantly increased the expression level of eNOS and phosphorylated vasodilator-stimulated phosphoprotein and cGMP concentration in blood plasma and reduced intracellular and vascular cell adhesion molecules-1 production (109). The same dose of AVE3085 was given over 8 wk to DAHL salt-sensitive rats with diastolic heart failure. Cardiac hypertrophy and fibrosis were attenuated compared with those in untreated animals with diastolic ventricular dysfunction (149). Unfortunately, more clinical data regarding the effectiveness or safety of these eNOS enhancers are not yet available.

\section{Caveolins and Coexpression Partners}

Caveolins are a family of caveolar proteins composed of three isoforms. Caveolin-1 (Cav-1), a 22-kDa protein of 178 amino acids that oligomerizes and inserts into the cytoplasmic face of the caveolae (88), is expressed in a diverse range of cell types of the cardiovascular system, including endothelial cells, smooth muscle cells, and cardiac fibroblasts. Interestingly, although Cav-2 is dispensable for forming caveolae, it is very often coexpressed with Cav-1 in many of these cells. Cav-3 is a 151 amino acid protein that shares $65 \%$ identity and $85 \%$ similarity with Cav-1. Its expression is mainly muscular specific and predominant in striated muscle cells. In the heart it is located in cardiac myocytes (150). Mutations in the Cav-3 gene in humans are associated with pathological cardiac hypertrophy, and Cav-3 $3^{-1-}$ mice also develop a progressive cardiomy- opathy (154). Research on the role of caveolins in cardiovascular diseases has mainly focused on Cav-1. In vitro and in vivo studies in Cav-1 $1^{-/}$mice have identified Cav-1 as an inhibitory modulator of eNOS $(163,164)$. However, the role of Cav-1 in facilitating or preventing eNOS dimerization remains unclear. The $\mathrm{NH}_{2}$-terminal oligomerization domain (amino acids 61-101) and the residues 135-178 located in the COOHterminal tail are two cytoplasmic domains of Cav-1 interacting with eNOS. Ghosh et al. (47) proposed that the eNOS reductase domain binding sites of Cav-1 antagonize the calmodulin (CaM) binding to eNOS and electron transfer to the eNOS heme, thereby inhibiting heme iron reduction and NO synthesis. eNOS is the bridge holding the eNOS/Cav-1/heat shock protein-90 (Hsp90) heterotrimeric complex together. CaM cannot physically disrupt the eNOS-caveolin complex in vitro, but Hsp90 can facilitate $\mathrm{CaM}$ to displace caveolin from eNOS (45).

Understanding the interaction between Cav-1 and eNOS and its impact on eNOS activity is critical for the interpretation of the posttranslational regulations of this enzyme. When the intracellular calcium concentration increases, calcium/ $\mathrm{CaM}$ interrupts the heteromeric complex of Cav-1 and eNOS. CaM then acts as a direct allosteric competitor of Cav-1 to promote the calcium-dependent activation of eNOS (85). Other groups demonstrated that Cav-1 was not absolutely required for targeting eNOS to caveolae/lipid rafts, suggesting the involvements of other important molecular partners $(49,125)$. Two other proteins named as eNOS-interacting protein (NOSIP) and eNOS traffic inducer (NOSTRIN) that specifically modulate the caveolin/eNOS interaction have been described $(33,113$, 165). NOSTRIN also functions as an adaptor protein to recruit dynamin-2, which is a large GTPase and a positive modulator of eNOS (118) to facilitate internalization of eNOS (113).

GTP cyclohydrolase I (GTPCH I) was found to be colocalized with Cav-1 within caveolae, and its activity was reversely regulated by Cav-1 (105). The coexpression of the arginine transporter-1, Cav-1, and eNOS was demonstrated within caveolae (82). Caveolae were reported to represent the calcium channels of the plasma membrane (44). Thus these flaskshaped vesicular invaginations, caveolae, bring eNOS in close proximity to molecules that are required for its proper function.

The tight interaction between Cav-1 and eNOS and its importance in cardiovascular system lead to numerous investigations in Cav-1 $1^{-/-}$mouse models and contributed to a better understanding of the pathogenesis of cardiovascular diseases. eNOS activity is upregulated in $\mathrm{Cav}-1^{-1-}$ animals, and this activity can be blunted by using a specific NOS inhibitor, L-NAME (107). Cav-1 deficiency induces a variety of cardiovascular pathological phenotypes, including cardiac hypertrophy, pulmonary arterial hypertension, atherosclerosis, and defective angiogenesis. According to Feron et al. (39), a hypercholesterolemia-induced decrease in NO production is ascribed to an enhanced interaction of Cav-1 and eNOS. Interestingly, the protective role of the complete loss of Cav-1 on the development of aortic atherosclerosis has been demonstrated in ApoE $\mathrm{E}^{-1-}$-deficient mice (42). Cav-1 ${ }^{-1-}$ mice also showed hyperproliferative and vascular abnormalities (107). Surprisingly, some of these cardiovascular symptoms were attributed to an increased Cav-1 abundance as well. Under basal conditions, Cav-1 maintains eNOS in its inactivated state and limits NO production, whereas in the case of reduced Cav-1 expres- 
sion (e.g., Cav-1 $1^{-l-}$ animals), eNOS expression and NO release are significantly increased. Agonist- stimulated receptor/ effector leads to eNOS activation through a local increase of intracellular calcium, dissociation from Cav-1, and subsequent formation of CaM/eNOS. When Cav-1 abundance falls below a certain threshold level, the coupling between agonist-bound receptor and cytosolic eNOS is lost and NO production is decreased. When the abundance of caveolin is increased, eNOS is inactivated by this excess inhibitory clamping, preventing the activation of the receptor signaling cascade and resulting in reduced NO production (38).

More recently, the inhibition of $\delta$-PKC and the activation of $\varepsilon$-PKC were reported to promote the inactivation of eNOS by Cav-1 (93). This provides a novel perspective on the regulation of Cav-1/eNOS. In addition, an overexpression of Cav-1 enhanced eNOS trafficking to the plasma membrane and NO generation increased in response to shear stress and $\mathrm{H}_{2} \mathrm{O}_{2}$ (136). Estrogens mediate rapid eNOS activation via estrogen receptor- $\alpha$ within the plasma membrane of endothelial cells. Cav-1 stimulates $17 \beta$-estradiol-induced NO production by promoting estrogen receptor- $\alpha$ to the plasma membrane, which facilitates the activation of the phosphatidylinositol 3-kinase pathway, leading to eNOS activation and NO generation (60, 130). 3-Hydroxy-3-methylglutaryl-CoA reductase inhibitors can improve the impaired endothelial dysfunction of the aorta in spontaneously hypertensive rats and may activate eNOS by phosphorylation and a decrease of Cav-1 abundance (131). In contrast, a 24-h treatment of C-reactive protein increased eNOS binding to Cav-1 in human aortic endothelial cells, thereby negatively regulating eNOS (141). Methyl- $\beta$-cyclodextrin can inhibit caveolae-mediated endocytosis by moving cholesterol out of lysosomes and prevent eNOS-dependent NO production at the same time (80). However, no clinical data on the effects of methyl- $\beta$-cyclodextrin as an eNOS modulator in cardiovascular diseases are available.

\section{Phosphorylation of eNOS}

eNOS activity is also posttranslationally regulated by phosphorylations at different residues. The phosphorylation of eNOS at Ser ${ }^{114,615,633,1177}$ and $\mathrm{Thr}^{495}$ influences its activity in endothelial cells. So far, the knowledge of eNOS phosphorylation in cardiac myocytes is restricted to $\operatorname{Ser}^{1177}$ (94). Hsp90 is thought to be crucial for Akt-induced phosphorylation of eNOS-Ser ${ }^{1177}$ (16). Thus a binding complex of Hsp90, Akt, and CaM-bound eNOS is proposed to facilitate the proper function of eNOS.

\section{Other Modulator of eNOS Pathway: Netrin-1}

Netrin-1, a laminin-related secreted protein produced by floor plate cells, is well known for its crucial roles in the pathfinding of axon, cell proliferation, and migration during neuronal development (84). It has been implicated in angiogenic signaling in cardiovascular diseases and tumorigenesis with a controversial role, either pro- or anti-angiogenic (21). Recently, Zhang and Cai (161) demonstrated that netrin-1 activates its "deleted in colorectal cancer" (DCC) receptor in C57BL/6J mouse's cardiomyocytes and cardiac endothelial cells following $\mathrm{I} / \mathrm{R}$, results in the activation of extracellular signal-regulated kinase 1/2 (ERK1/2), and subsequently phosphorylates serine ${ }^{1177}$ of eNOS (p-eNOSs1177), thus increasing
NO production. NO also contributes to ERK1/2 activation, and netrin-1-induced DCC upregulation can be abolished by U-0126 (MEK1/2 inhibitor), L-NAME, or 2-(4-carboxyphenyl)-4,4,5,5-tetramethylinmidazoline-1-oxide (PTIO; NO scavenger), thus forming a feed-forward cycle. Based on these findings, a netrin-1/DCC/ERK1/2/eNOSs1177/NO/DCC feedforward mechanism was identified as a molecular paradigm subsequently found to also operate in adult aortic endothelial cells. Because in the absence of netrin-1, its receptors can trigger apoptosis, netrin-1 has been suggested as the target in cancer therapy (83). Although studies on netrin-1 as a cardioprotectant are still at a very early stage, these findings highlight its potential as a novel cardioprotective mediator in cardiovascular disease.

\section{S-glutathionylation of eNOS}

Recently, Zweier et al. (22) elegantly demonstrated that under oxidative stress, the two highly conserved cysteine 689 and 908 residues at the interface between the flavin mononucleotide-binding and FAD-binding domains of eNOS in endothelial cells can be $S$-glutathionylated, triggering eNOS uncoupling with increased superoxide production. $S$-glutathionylation is increased in hypertensive vessels with impaired endothelium-dependent vasodilation and can be reversed by thiol-reducing agents. Thus therapeutics with thiol-reducing properties have a great potential to be further developed as potent drugs for cardiovascular disease in which the pathogenetic importance of eNOS uncoupling has been identified (22).

Experimental (genetic) models for studying eNOS modulation. The generation and characterization of mice with a targeted disruption of the individual gene products responsible for NO production has greatly advanced our understanding of cardiovascular homeostasis and the pivotal roles of the different NOS isoforms in the pathogenesis of cardiovascular diseases. The inactivation of the neuronal, inducible, and endothelial NOS genes, either individually or in combination, has led to the development of a variety of mutant mice with distinct cardiovascular phenotypes. In concept, these mice have clearly demonstrated the impact of $\mathrm{NO}$ on blood pressure regulation, endothelial dysfunction, response to vascular injury, myocardial and brain ischemia, development of atherosclerosis, and cardiac contractility. While the individual knockout models complement and refine pharmacological approaches with (non) selective NOS inhibitors, they can be confounded by developmental abnormalities, secondary adaptations in pathways acting upstream or downstream to the gene product of interest, or reciprocal changes in expression of proteins that compensate for the deleted gene product (121).

Similarly, the generation of genetically engineered mice with cell-specific overexpression of NOS isoforms has enabled a unique appreciation of the ability of NO to modulate vascular and cardiac function. These experimental models represent a powerful tool to study their function in vivo, independent of changes in cardiac contractility and loading conditions, and provide important insights in the significance of NOS isoforms in human cardiovascular diseases $(59,77,95,101)$.

The different exons of mouse eNOS genes had originally been ruled out for study in relation to cardiovascular diseases during the 1990s [exons 24 and 25 (48), exons 24-26 (55), and exon 12 (120)]. The first eNOS overexpressing mouse model 


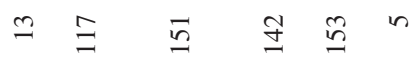
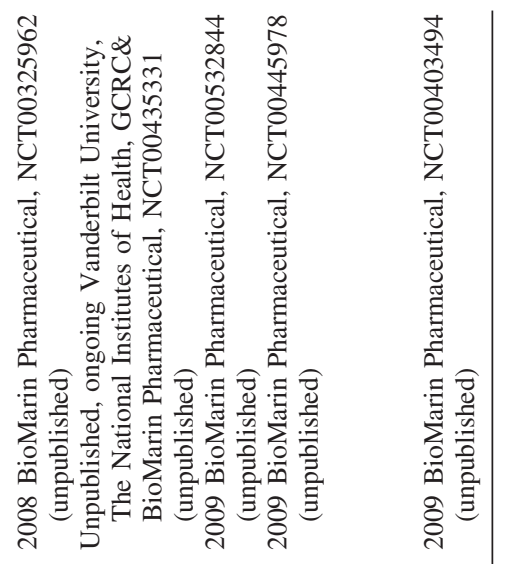

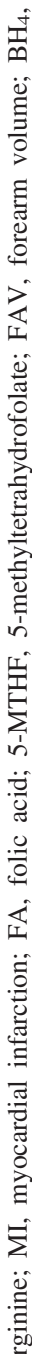
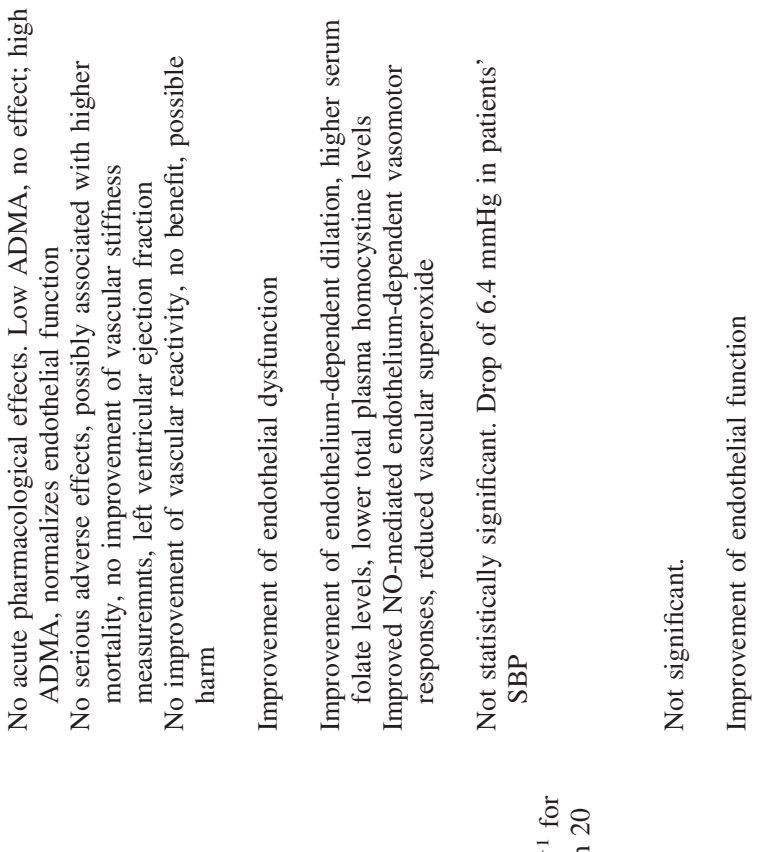

호요

芯

君害

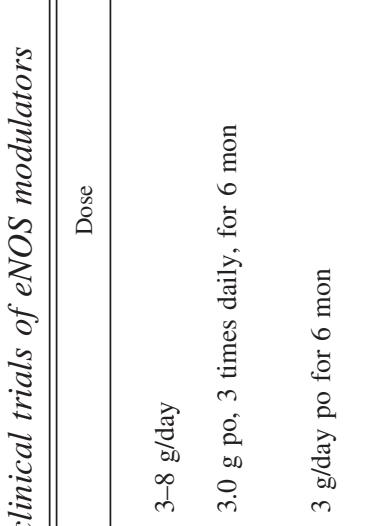

$\stackrel{0}{\circ}$

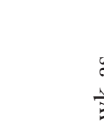

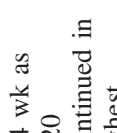

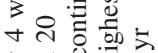
$\because \frac{1}{3}$ 至

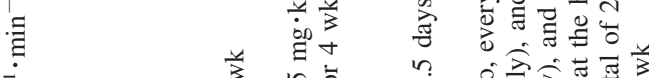

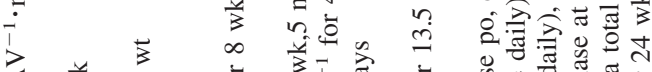

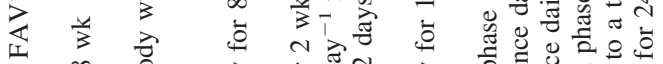
西要㐘

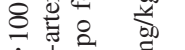

施焉蛋

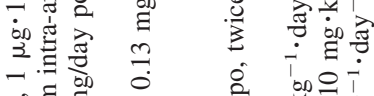

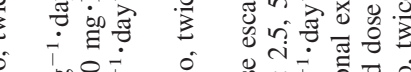

年

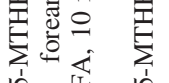

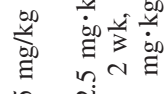

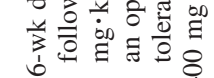


expressing bovine eNOS in the vascular wall by using murine preproendothelin-1 promotor was generated by Ohashi et al. (101), a random insertion of the human eNOS DNA fragment into mouse genes and driven by the native eNOS promoter later generated by R. van Haperen (143).

Single vs. combined NOS knockout mice. The targeted deletion of eNOS has revealed a fundamental role of this isoform in the functional and structural responses of the vessel wall to metabolic and mechanical stress and of the heart to ischemic injury and pressure and volume overload. Several strains of eNOS knockout mice have showed significant systemic hypertension, which unequivocally confirmed a critical role of basal NO production in blood pressure regulation (121). In addition, these mice showed an increased neointimal formation and abnormal vascular remodeling in response to vascular injury and an accelerated atherosclerotic lesion formation when crossbred with $\mathrm{ApoE}^{-1-}$ mice. When subjected to coronary artery ligation, they showed an impaired survival, a greater contractile dysfunction, and a weakened LV remodeling. Of interest, very similar vascular injury and atherosclerotic phenotypes have been described in neuronal NOS-knockout $\left(\mathrm{nNOS}^{-1-}\right)$ mice, and the observations that the nNOS gene is upregulated with vascular injury in wild-type mice suggests a compensatory role in the presence of reduced eNOS activity.

In contrast, the targeted deletion of iNOS led to a blunted hypotensive response to sepsis, which in wild-type mice is caused by inappropriate vasodilation when NO is produced in large quantities. The vascular injury phenotype of $\mathrm{iNOS}^{-1-}$ mice is more complex with vasculoprotection or exacerbation of the lesion depending on oxidant or antioxidant conditions, which in turn is dictated by the balance between NO and ROS generation and substrate and cofactor availability (121).

Because the phenotypic interpretation of mutant mice with deletion of a single NOS isoform might be confounded by compensatory interactions between residual NOS isoforms, the ultimate role of endogenous $\mathrm{NO}$ in cardiovascular disease can best be appreciated in triply deficient NOS $1-2-3^{-/-}$mice. The phenotype of combined mutants closely resembles aging, metabolic syndrome in humans with marked activation of the renin-angiotensin system, and nephrogenic diabetes insipidus and manifests marked coronary atherosclerotic lesions, spontaneous myocardial infarction, and sudden death (97). Taken together, so far these observations provide the best evidence for a central role of defective NO production in the pathogenesis of cardiovascular disease.

Transgenic eNOS overexpression. Consistent with observations in eNOS knockout mice, genetically engineered mice with endothelial cell-specific eNOS overexpression showed mild hypotension, variable atherogenesis when backcrossed with $\mathrm{ApoE}^{-1-}$ mice, and a reduction in I/R injury and postinfarction heart failure. The underlying mechanisms were proposed to resemble those implicated in the beneficial effects of NO-donor compounds in similar disease conditions, including decreased leukocyte and platelet activation and reduced afterload through potent vasodilation (12). Alternatively, mice with cardiac myocyte-restricted eNOS overexpression showed a blunted chronotropic and inotropic response to catecholamines and a better-preserved systolic and diastolic function after myocardial infarction with reduced dilation of the LV (59).

These studies in NOS-deficient and eNOS-overexpressing mice have emphasized the importance of cellular and even subcellular isoform localization in mouse models of human cardiovascular disease. However, the observations that under conditions of $\mathrm{BH}_{4}$ or L-arginine deficiency and enhanced oxidative stress, eNOS-derived NO may contribute to atherogenesis, deleterious LV remodeling, and vascular (cross-)tolerance to endothelium-dependent relaxation emphasize the critical role of cofactors and substrate in determining the balance between eNOS-mediated protection or harm $(102,133)$.

\section{Discussion}

The biochemical, molecular, biological, and experimental evidence supports an important role of eNOS uncoupling in endothelial and myocardial dysfunction associated with many cardiovascular diseases. Accordingly, stabilizing NOS function and suppressing NOS-derived ROS production is a compelling strategy to translational studies in patients with a wide spectrum of cardiovascular disease. There is a great need for significant trials that further explore the importance of eNOS uncoupling in the primary phases of the onset of the different cardiovascular diseases. An overview of selected clinical trials of eNOS modulators are provided in Table 1 . In addition, more knowledge is needed to obtain "preferably clinical" data regarding the effect of eNOS modulation on the other parts of NO-signaling pathways. To our knowledge no clinical data exist on the acute and long-term effects of $\mathrm{BH}_{4}$ administration on NO generation in other organs and on iNOS activity.

The different transgenic mouse models provide the necessary foundation for future translation into novel clinical approaches to prevent and treat cardiovascular disease. Whether enhanced NO bioavailability will best be achieved through local NOS gene transfer, or NO inhalation, local delivery of next-generation NO-donor compounds or eNOS cofactors remains to be tested in focused translational studies.

\section{GRANTS}

This study was supported by the Dutch Heart Foundation National Health Service Subsidy 2009 and Dutch government ZonMw/Vidi and Aspasia program (both to A. L. Moens), EU FP7 Marie Curie Action IRG 268235 (to H. H. H. W. Schmidt), the National Health and Medical Research Council of Australia (to H. H. H. W. Schmidt), and by the Research Council KU-Leuven PF/10/014 — C1902 (to S. P. Janssens).

\section{DISCLOSURES}

No conflicts of interest, financial or otherwise, are declared by the author(s).

\section{REFERENCES}

1. Aigrain L, Pompon D, Truan G. Role of the interface between the FMN and FAD domains in the control of redox potential and electronic transfer of NADPH-cytochrome P450 reductase. Biochem J 435: 197206, 2011.

2. Al-Zobaidy MJ, Craig J, Martin W. Differential sensitivity of basal and acetylcholine-induced activity of nitric oxide to blockade by asymmetric dimethylarginine in the rat aorta. Br J Pharmacol 160: 14761483, 2010.

3. Antoniades C, Shirodaria C, Crabtree M, Rinze R, Alp N, Cunnington C, Diesch J, Tousoulis D, Stefanadis C, Leeson P. Altered plasma versus vascular biopterins in human atherosclerosis reveal relationships between endothelial nitric oxide synthase coupling, endothelial function, and inflammation. Circulation 116: 2851-2859, 2007.

4. Antoniades C, Shirodaria C, Leeson P, Antonopoulos A, Warrick N, Van-Assche T, Cunnington C, Tousoulis D, Pillai R, Ratnatunga C, Stefanadis C, Channon KM. Association of plasma asymmetrical dimethylarginine (ADMA) with elevated vascular superoxide production and endothelial nitric oxide synthase uncoupling: implications for endo- 
thelial function in human atherosclerosis. Eur Heart $J$ 30: 1142-1150, 2009.

5. Antoniades C, Shirodaria C, Warrick N, Cai S, de Bono J, Lee J, Leeson P, Neubauer S, Ratnatunga C, Pillai R. 5-Methyltetrahydrofolate rapidly improves endothelial function and decreases superoxide production in human vessels: effects on vascular tetrahydrobiopterin availability and endothelial nitric oxide synthase coupling. Circulation 114: 1193-1201, 2006.

6. Aoki C, Nakano A, Tanaka S, Yanagi K, Ohta S, Jojima T, Kasai K, Takekawa H, Hirata K, Hattori Y. Fluvastatin upregulates endothelial nitric oxide synthase activity via enhancement of its phosphorylation and expression and via an increase in tetrahydrobiopterin in vascular endothelial cells. Int J Cardiol 2010 Nov 17. [Epub ahead of print]

7. Bendall J, Alp N, Warrick N, Cai S, Adlam D, Rockett K, Yokoyama M, Kawashima S, Channon K. Stoichiometric relationships between endothelial tetrahydrobiopterin, endothelial NO synthase (eNOS) activity, and eNOS coupling in vivo: insights from transgenic mice with endothelial-targeted GTP cyclohydrolase 1 and eNOS overexpression. Circ Res 97: 864-871, 2005.

8. Berbee M, Fu Q, Boerma M, Pathak R, Zhou D, Kumar K, HauerJensen M. Reduction of radiation-induced vascular nitrosative stress by the vitamin E Analog $\gamma$-tocotrienol: evidence of a role for tetrahydrobiopterin. Int J Radiat Oncol Bio Phys 79: 884-891, 2010.

9. Berka V, Wu G, Yeh HC, Palmer G, Tsai AL. Three different oxygen-induced radical species in endothelial nitric-oxide synthase oxygenase domain under regulation by L-arginine and tetrahydrobiopterin. J Biol Chem 279: 32243-32251, 2004.

10. Berry CE, Hare JM. Xanthine oxidoreductase and cardiovascular disease: molecular mechanisms and pathophysiological implications. $J$ Physiol 555: 589-606, 2004.

11. Bevers L, Braam B, Post J, van Zonneveld A, Rabelink T, Koomans H, Verhaar M, Joles J. Tetrahydrobiopterin, but not L-arginine, decreases NO synthase uncoupling in cells expressing high levels of endothelial NO synthase. Hypertension 47: 87-94, 2006.

12. Bloch KD, Janssens S. Cardiomyocyte-specific overexpression of nitric oxide synthase 3: impact on left ventricular function and myocardial infarction. Trends Cardiovasc Med 15: 249-253, 2005.

13. Boger RH. The pharmacodynamics of L-arginine. J Nutr 137: 1650S1655S, 2007.

14. Boger RH, Tsikas D, Bode-Boger SM, Phivthong-Ngam L, Schwedhelm E, Frolich JC. Hypercholesterolemia impairs basal nitric oxide synthase turnover rate: a study investigating the conversion of L-[guanidino-(15) N(2)]-arginine to (15)N-labeled nitrate by gas chromatography-mass spectrometry. Nitric Oxide 11: 1-8, 2004.

15. Bonaa K, Njolstad I, Ueland P, Schirmer H, Tverdal A, Steigen T, Wang H, Nordrehaug J, Arnesen E, Rasmussen K. Homocysteine lowering and cardiovascular events after acute myocardial infarction. $N$ Engl J Med 354: 1578-1588, 2006.

16. Brouet A, Sonveaux P, Dessy C, Balligand JL, Feron O. Hsp90 ensures the transition from the early $\mathrm{Ca}^{2+}$-dependent to the late phosphorylation-dependent activation of the endothelial nitric-oxide synthase in vascular endothelial growth factor-exposed endothelial cells. $J$ Biol Chem 276: 32663-32669, 2001

17. Bryan NS, Fernandez BO, Bauer SM, Garcia-Saura MF, Milsom AB, Rassaf T, Maloney RE, Bharti A, Rodriguez J, Feelisch M. Nitrite is a signaling molecule and regulator of gene expression in mammalian tissues. Nat Chem Biol 1: 290-297, 2005.

18. Burner U, Furtmüller PG, Kettle AJ, Koppenol WH, Obinger C. Mechanism of reaction of myeloperoxidase with nitrite. J Biol Chem 275: 20597-20601, 2000.

19. Calvert JW, Lefer DJ. Clinical translation of nitrite therapy for cardiovascular diseases. Nitric Oxide 22: 91-97, 2010.

20. Cardounel AJ, Cui H, Samouilov A, Johnson W, Kearns P, Tsai AL, Berka V, Zweier JL. Evidence for the pathophysiological role of endogenous methylarginines in regulation of endothelial NO production and vascular function. J Biol Chem 282: 879-887, 2007.

21. Castets M, Mehlen P. Netrin-1 role in angiogenesis: to be or not to be a pro-angiogenic factor? Cell Cycle 9: 1466-1471, 2010.

22. Chen CA, Wang TY, Varadharaj S, Reyes LA, Hemann C, Talukder MA, Chen YR, Druhan LJ, Zweier JL. S-glutathionylation uncouples eNOS and regulates its cellular and vascular function. Nature 468: 1115-1118, 2010.

23. Chen CH, Sun L, Mochly-Rosen D. Mitochondrial aldehyde dehydrogenase and cardiac diseases. Cardiovasc Res 88: 51-57, 2010.
24. Chen W, Druhan LJ, Chen CA, Hemann C, Chen YR, Berka V, Tsai AL, Zweier JL. Peroxynitrite induces destruction of the tetrahydrobiopterin and heme in endothelial nitric oxide synthase: transition from reversible to irreversible enzyme inhibition. Biochemistry 49: 31293137, 2010.

25. Chen YR. Involvement of protein radical, protein aggregation, and effects on NO metabolism in the hypochlorite-mediated oxidation of mitochondrial cytochrome c. Free Radic Biol Med 37: 1591-1603, 2004.

26. Cosby K, Partovi KS, Crawford JH, Patel RP, Reiter CD, Martyr S, Yang BK, Waclawiw MA, Zalos G, Xu X, Huang KT, Shields H, Kim-Shapiro DB, Schechter AN, Cannon RO 3rd, Gladwin MT. Nitrite reduction to nitric oxide by deoxyhemoglobin vasodilates the human circulation. Nat Med 9: 1498-1505, 2003.

27. Cosentino F, Patton S. Tetrahydrobiopterin alters superoxide and nitric oxide release in prehypertensive rats. J Clin Invest 101: 1530-1537, 1998.

28. Crabtree MJ, Tatham AL, Al-Wakeel Y, Warrick N, Hale AB, Cai S, Channon KM, Alp NJ. Quantitative regulation of intracellular endothelial nitric-oxide synthase (eNOS) coupling by both tetrahydrobiopterineNOS stoichiometry and biopterin redox status: insights from cells with tet-regulated GTP cyclohydrolase I expression. J Biol Chem 284: 11361144, 2009.

29. Crabtree MJ, Tatham AL, Hale AB, Alp NJ, Channon KM. Critical role for tetrahydrobiopterin recycling by dihydrofolate reductase in regulation of endothelial nitric-oxide synthase coupling. J Biol Chem 284: 28128-28163, 2009.

30. Cunnington C, Channon KM. Tetrahydrobiopterin: pleiotropic roles in cardiovascular pathophysiology. Heart 96: 1872-1877, 2010.

31. d'Uscio LV, Milstien S, Richardson D, Smith L, Katusic ZS. Longterm vitamin $\mathrm{C}$ treatment increases vascular tetrahydrobiopterin levels and nitric oxide synthase activity. Circ Res 92: 88-95, 2003.

32. De Castro S, Leung K, Savery D, Burren K, Rozen R, Copp A, Greene N. Neural tube defects induced by folate deficiency in mutant curly tail (Grhl3) embryos are associated with alteration in folate one carbon metabolism but are unlikely to result from diminished methylation. Birth Defects Res A Clin Mol Teratol 88: 612-618, 2010.

33. Dedio J, Konig P, Wohlfart P, Schroeder C, Kummer W, MullerEsterl W. NOSIP, a novel modulator of endothelial nitric oxide synthase activity. FASEB $J$ 15: 79-89, 2001.

34. Druhan LJ, Forbes SP, Pope AJ, Chen CA, Zweier JL, Cardounel AJ. Regulation of eNOS-derived superoxide by endogenous methylarginines. Biochemistry 47: 7256-7263, 2008.

35. Dumitrescu C, Biondi R, Xia Y, Cardounel AJ, Druhan LJ, Ambrosio G, Zweier JL. Myocardial ischemia results in tetrahydrobiopterin (BH4) oxidation with impaired endothelial function ameliorated by BH4. Proc Natl Acad Sci USA 104: 15081-15086, 2007.

36. Durand P, Prost M, Blache D. Pro-thrombotic effects of a folic acid deficient diet in rat platelets and macrophages related to elevated homocysteine and decreased n-3 polyunsaturated fatty acids. Atherosclerosis 121: 231-243, 1996.

37. Erwin PA, Lin AJ, Golan DE, Michel T. Receptor-regulated dynamic $S$-nitrosylation of endothelial nitric-oxide synthase in vascular endothelial cells. J Biol Chem 280: 19888-19894, 2005.

38. Feron O, Balligand J. Caveolins and the regulation of endothelial nitric oxide synthase in the heart. Cardiovasc Res 69: 788-797, 2006.

39. Feron O, Dessy C, Moniotte S, Desager J, Balligand J. Hypercholesterolemia decreases nitric oxide production by promoting the interaction of caveolin and endothelial nitric oxide synthase. J Clin Invest 103: 897-905, 1999.

40. Fiorucci S, Santucci L, Gresele P, Faccino RM, del Soldato P, Morelli A. Gastrointestinal safety of NO-aspirin (NCX-4016) in healthy human volunteers: a proof of concept endoscopic study. Gastroenterology 124: 600-607, 2003.

41. Fraccarollo D, Widder J, Galuppo P, Thum T, Tsikas D, Hoffmann M, Ruetten H, Ertl G, Bauersachs J. Improvement in left ventricular remodeling by the endothelial nitric oxide synthase enhancer AVE9488 after experimental myocardial infarction. Circulation 118: 818-827, 2008.

42. Frank P, Lee H, Park D, Tandon N, Scherer P, Lisanti M. Genetic ablation of caveolin-1 confers protection against atherosclerosis. Arterioscler Thromb Vasc Biol 24: 98-105, 2004.

43. Frantz S, Adamek A, Fraccarollo D, Tillmanns J, Widder J, Dienesch C, Schäfer A, Podolskaya A, Held M, Ruetten H. The eNOS 
enhancer AVE 9488: a novel cardioprotectant against ischemia reperfusion injury. Basic Res Cardiol 104: 773-779, 2009.

44. Fujimoto T. Calcium pump of the plasma membrane is localized in caveolae. J Cell Biol 120: 1147-1157, 1993.

45. Fulton D, Gratton J, Sessa W. Post-translational control of endothelial nitric oxide synthase: why isn't calcium/calmodulin enough? J Pharmacol Exp Ther 299: 818-824, 2001.

46. Gao YT, Roman LJ, Martasek P, Panda SP, Ishimura Y, Masters BS. Oxygen metabolism by endothelial nitric-oxide synthase. J Biol Chem 282: 28557-28565, 2007.

47. Ghosh S, Gachhui R, Crooks C, Wu C, Lisanti M, Stuehr D. Interaction between caveolin-1 and the reductase domain of endothelial nitric-oxide synthase. J Biol Chem 273: 22267-22271, 1998.

48. Godecke A, Decking UK, Ding Z, Hirchenhain J, Bidmon HJ, Godecke S, Schrader J. Coronary hemodynamics in endothelial NO synthase knockout mice. Circ Res 82: 186-194, 1998.

49. Gonzalez E, Nagiel A, Lin A, Golan D, Michel T. Small interfering RNA-mediated down-regulation of caveolin-1 differentially modulates signaling pathways in endothelial cells. J Biol Chem 279: 40659-40669, 2004.

50. Gori T, Parker JD. The puzzle of nitrate tolerance: pieces smaller than we thought? Circulation 106: 2404-2408, 2002.

51. Hasegawa H, Sawabe K, Nakanishi N, Wakasugi OK. Delivery of exogenous tetrahydrobiopterin (BH4) to cells of target organs: role of salvage pathway and uptake of its precursor in effective elevation of tissue BH4. Mol Genet Metab 86, Suppl 1: S2-S10, 2005.

52. Heller R, Unbehaun A, Schellenberg B, Mayer B, Werner-Felmayer G, Werner E. L-ascorbic acid potentiates endothelial nitric oxide synthesis via a chemical stabilization of tetrahydrobiopterin. J Biol Chem 276: 40-47, 2001.

53. Henning S, Swendseid M, Ivandic B, Liao F. Vitamins C, E and A and heme oxygenase in rats fed methyl/folate-deficient diets. Free Radic Biol Med 23: 936-942, 1997.

54. Huang HS, Ma MC, Chen J. Chronic L-arginine administration increases oxidative and nitrosative stress in rat hyperoxaluric kidneys and excessive crystal deposition. Am J Physiol Renal Physiol 295: F388F396, 2008 .

55. Huang PL, Huang Z, Mashimo H, Bloch KD, Moskowitz MA, Bevan JA, Fishman MC. Hypertension in mice lacking the gene for endothelial nitric oxide synthase. Nature 377: 239-242, 1995.

56. Hyndman M, Verma S, Rosenfeld R, Anderson T, Parsons H. Interaction of 5-methyltetrahydrofolate and tetrahydrobiopterin on endothelial function. Am J Physiol Heart Circ Physiol 282: H2167-H2172, 2002.

57. Institute of Medicine, Food, and Nutrition Board. Dietary Reference Intake: Folate. Washington, DC: National Academy Press, 1998.

58. ISIS-4-Group. ISIS-4: a randomised factorial trial assessing early oral captopril, oral mononitrate, and intravenous magnesium sulphate in 58,050 patients with suspected acute myocardial infarction. ISIS-4 (Fourth International Study of Infarct Survival) Collaborative Group. Lancet 345: 669-685, 1995.

59. Janssens S, Pokreisz $\mathbf{P}$, Schoonjans L, Pellens $\mathbf{M}$, Vermeersch $\mathbf{P}$, Tjwa M, Jans P, Scherrer-Crosbie M, Picard MH, Szelid Z, Gillijns H, Van de Werf F, Collen D, Bloch KD. Cardiomyocyte-specific overexpression of nitric oxide synthase 3 improves left ventricular performance and reduces compensatory hypertrophy after myocardial infarction. Circ Res 94: 1256-1262, 2004.

60. Jayachandran M, Hayashi T, Sumi D, Iguchi A, Miller V. Temporal effects of $17 \beta$-estradiol on caveolin- $1 \mathrm{mRNA}$ and protein in bovine aortic endothelial cells. Am J Physiol Heart Circ Physiol 281: H1327-H1333, 2001.

61. Kapil V, Webb A, Ahluwalia A. Inorganic nitrate and the cardiovascular system. Heart 96: 1703-1709, 2010.

62. Katusic ZS, d'Uscio LV, Nath KA. Vascular protection by tetrahydrobiopterin: progress and therapeutic prospects. Trends Pharmacol Sci 30: 48-54, 2009.

63. Klatt P, Schmidt K, Lehner D, Glatter O, Bachinger HP, Mayer B. Structural analysis of porcine brain nitric oxide synthase reveals a role for tetrahydrobiopterin and L-arginine in the formation of an SDS-resistant dimer. EMBO J 14: 3687-3695, 1995.

64. Klemenska E, Bersewicz A. Bioactivation of organic nitrates and the mechanism of nitrate tolerance. Cardiol J 16: 11-19, 2008.

65. Kotsonis P, Frohlich LG, Shutenko ZV, Horejsi R, Pfleiderer W, Schmidt HH. Allosteric regulation of neuronal nitric oxide synthase by tetrahydrobiopterin and suppression of auto-damaging superoxide. Biochem J 346: 767-776, 2000.

66. Kunuthur S, Milliken P, Gibson C, Suckling C, Wadsworth R. Tetrahydrobiopterin analogues with NO-dependent pulmonary vasodilator properties. Eur J Pharmacol 650: 371-377, 2010.

67. Kuzkaya N, Weissmann N, Harrison D, Dikalov S. Interactions of peroxynitrite, tetrahydrobiopterin, ascorbic acid, and thiols. J Biol Chem 278: 22546-22554, 2003.

68. Landmesser U, Dikalov S, Price S, McCann L, Fukai T, Holland S, Mitch W, Harrison D. Oxidation of tetrahydrobiopterin leads to uncoupling of endothelial cell nitric oxide synthase in hypertension. $J$ Clin Invest 111: 1201-1209, 2003.

69. Leopold JA, Loscalzo J. Oxidative enzymopathies and vascular disease. Arterioscler Thromb Vasc Biol 25: 1332-1340, 2005.

70. Li H, Forstermann U. Prevention of atherosclerosis by interference with the vascular nitric oxide system. Curr Pharm Des 15: 3133-3145, 2009.

71. Li H, Kundu TK, Zweier JL. Characterization of the magnitude and mechanism of aldehyde oxidase-mediated nitric oxide production from nitrite. J Biol Chem 284: 33850-33858, 2009.

72. Li H, Samouilov A, Liu X, Zweier JL. Characterization of the magnitude and kinetics of xanthine oxidase-catalyzed nitrate reduction: evaluation of its role in nitrite and nitric oxide generation in anoxic tissues. Biochemistry 42: 1150-1159, 2003.

73. List BM, Klosch B, Volker C, Gorren AC, Sessa WC, Werner ER, Kukovetz WR, Schmidt K, Mayer B. Characterization of bovine endothelial nitric oxide synthase as a homodimer with down-regulated uncoupled NADPH oxidase activity: tetrahydrobiopterin binding kinetics and role of haem in dimerization. Biochem J 323: 159-165, 1997.

74. Liu X, Huang Y, Pokreisz P, Vermeersch P, Marsboom G, Swinnen M, Verbeken E, Santos J, Pellens M, Gillijns H, Van de Werf F, Bloch KD, Janssens S. Nitric oxide inhalation improves microvascular flow and decreases infarction size after myocardial ischemia and reperfusion. J Am Coll Cardiol 50: 808-817, 2007.

75. Lonn E, Yusuf S, Arnold M, Sheridan P, Pogue J, Micks M, McQueen M, Probstfield J, Fodor G, Held C. Homocysteine lowering with folic acid and B vitamins in vascular disease. N Engl J Med 354: $1567-1577,2006$.

76. Loscalzo J. Folate and nitrate-induced endothelial dysfunction: a simple treatment for a complex pathobiology. Circulation 104: 1086-1088, 2001.

77. Loyer X, Gomez AM, Milliez P, Fernandez-Velasco M, Vangheluwe P, Vinet L, Charue D, Vaudin E, Zhang W, Sainte-Marie Y, Robidel E, Marty I, Mayer B, Jaisser F, Mercadier JJ, Richard S, Shah AM, Benitah JP, Samuel JL, Heymes C. Cardiomyocyte overexpression of neuronal nitric oxide synthase delays transition toward heart failure in response to pressure overload by preserving calcium cycling. Circulation 117: 3187-3198, 2008.

78. Lu X, Guo X, Wassall CD, Kemple MD, Unthank JL, Kassab GS. Reactive oxygen species cause endothelial dysfunction in chronic flowoverload. J Appl Physiol 110: 520-527, 2011.

79. Maia LB, Moura JJ. Nitrite reduction by xanthine oxidase family enzymes: a new class of nitrite reductases. J Biol Inorg Chem 16: 443-460, 2011.

80. Maniatis NA, Brovkovych V, Allen SE, John TA, Shajahan AN, Tiruppathi C, Vogel SM, Skidgel RA, Malik AB, Minshall RD. Novel mechanism of endothelial nitric oxide synthase activation mediated by caveolae internalization in endothelial cells. Circ Res 99: 870-877, 2006.

81. Mata-Greenwood E, Jenkins C, Farrow KN, Konduri GG, Russell JA, Lakshminrusimha S, Black SM, Steinhorn RH. eNOS function is developmentally regulated: uncoupling of eNOS occurs postnatally. Am J Physiol Lung Cell Mol Physiol 290: L232-L241, 2006.

82. McDonald KK, Zharikov S, Block ER, Kilberg MS. A caveolar complex between the cationic amino acid transporter 1 and endothelial nitric-oxide synthase may explain the "arginine paradox". J Biol Chem 272: 31213-31216, 1997.

83. Mehlen P, Guenebeaud C. Netrin-1 and its dependence receptors as original targets for cancer therapy. Curr Opin Oncol 22: 46-54, 2010.

84. Mehlen P, Rama N. Netrin-1 and axonal guidance: signaling and asymmetrical translation. [French.] Med Sci (Paris) 23: 311-315, 2007.

85. Michel J, Feron O, Sacks D, Michel T. Reciprocal regulation of endothelial nitric-oxide synthase by $\mathrm{Ca}^{2+}$-calmodulin and caveolin. $J$ Biol Chem 272: 15583-15586, 1997.

86. Miller OI, Tang SF, Keech A, Pigott NB, Beller E, Celermajer DS. Inhaled nitric oxide and prevention of pulmonary hypertension after 
congenital heart surgery: a randomised double-blind study. Lancet 356: 1464-1469, 2000.

87. Milstien S, Katusic Z. Oxidation of tetrahydrobiopterin by peroxynitrite: implications for vascular endothelial function. Biochem Biophys Res Commun 263: 681-684, 1999.

88. Minshall R, Sessa W, Stan R, Anderson R, Malik A. Caveolin regulation of endothelial function. Am J Physiol Lung Cell Mol Physiol 285: L1179-L1183, 2003.

89. Moens A, Champion H, Claeys M, Tavazzi B, Kaminski P, Wolin M, Borgonjon D, Van Nassauw L, Haile A, Zviman M. High-dose folic acid pretreatment blunts cardiac dysfunction during ischemia coupled to maintenance of high-energy phosphates and reduces postreperfusion injury. Circulation 117: 1810-1819, 2008.

90. Moens A, Kass D. Therapeutic potential of tetrahydrobiopterin for treating vascular and cardiac disease. J Cardiovasc Pharmacol 50: 238-246, 2007

91. Moens A, Takimoto E, Tocchetti C, Chakir K, Bedja D, Cormaci G, Ketner E, Majmudar M, Gabrielson K, Halushka M. Reversal of cardiac hypertrophy and fibrosis from pressure overload by tetrahydrobiopterin: efficacy of recoupling nitric oxide synthase as a therapeutic strategy. Circulation 117: 2626-2636, 2008.

92. Moens A, Vrints C, Claeys M, Timmermans J, Champion H, Kass D. Mechanisms and potential therapeutic targets for folic acid in cardiovascular disease. Am J Physiol Heart Circ Physiol 294: H1971-H1977, 2008.

93. Monti M, Donnini S, Giachetti A, Mochly-Rosen D, Ziche M. $\delta$-PKC inhibition or PKC activation repairs endothelial vascular dysfunction by regulating eNOS post-translational modification. J Mol Cell Cardiol 48: 746-756, 2010.

94. Mount PF, Kemp BE, Power DA. Regulation of endothelial and myocardial NO synthesis by multi-site eNOS phosphorylation. $J$ Mol Cell Cardiol 42: 271-279, 2007.

95. Mungrue IN, Gros R, You X, Pirani A, Azad A, Csont T, Schulz R, Butany J, Stewart DJ, Husain M. Cardiomyocyte overexpression of iNOS in mice results in peroxynitrite generation, heart block, and sudden death. J Clin Invest 109: 735-743, 2002.

96. Nagasaka Y, Fernandez BO, Garcia-Saura MF, Petersen B, Ichinose F, Bloch KD, Feelisch M, Zapol WM. Brief periods of nitric oxide inhalation protect against myocardial ischemia-reperfusion injury. Anesthesiology 109: 675-682, 2008.

97. Nakata S, Tsutsui M, Shimokawa H, Suda O, Morishita T, Shibata K, Yatera Y, Sabanai K, Tanimoto A, Nagasaki M, Tasaki H, Sasaguri Y, Nakashima Y, Otsuji Y, Yanagihara N. Spontaneous myocardial infarction in mice lacking all nitric oxide synthase isoforms. Circulation 117: 2211-2223, 2008.

98. Nossaman VE, Nossaman BD, Kadowitz PJ. Nitrates and nitrites in the treatment of ischemic cardiac disease. Cardiol Rev 18: 190-197, 2010.

99. Nossuli TO, Hayward R, Jensen D, Scalia R, Lefer AM. Mechanisms of cardioprotection by peroxynitrite in myocardial ischemia and reperfusion injury. Am J Physiol Heart Circ Physiol 275: H509-H519, 1998.

100. O'Connor DM, O'Brien T. Nitric oxide synthase gene therapy: progress and prospects. Expert Opin Biol Ther 9: 867-878, 2009.

101. Ohashi Y, Kawashima S, Hirata K, Yamashita T, Ishida T, Inoue N, Sakoda T, Kurihara H, Yazaki Y, Yokoyama M. Hypotension and reduced nitric oxide-elicited vasorelaxation in transgenic mice overexpressing endothelial nitric oxide synthase. J Clin Invest 102: 2061-2071, 1998.

102. Ozaki M, Kawashima S, Yamashita T, Hirase T, Namiki M, Inoue N, Hirata K, Yasui H, Sakurai H, Yoshida Y. Overexpression of endothelial nitric oxide synthase accelerates atherosclerotic lesion formation in apoE-deficient mice. J Clin Invest 110: 331-340, 2002.

103. Pant K, Crane BR. Structure of a loose dimer: an intermediate in nitric oxide synthase assembly. J Mol Biol 352: 932-940, 2005.

104. Parry TE. Folate responsive neuropathy. Presse Med 23: 131-137, 1994.

105. Peterson TE, d'Uscio LV, Cao S, Wang XL, Katusic ZS. Guanosine triphosphate cyclohydrolase I expression and enzymatic activity are present in caveolae of endothelial cells. Hypertension 53: 189-195, 2009.

106. Qipshidze N, Tyagi N, Sen U, Givvimani S, Metreveli N, Lominadze D, Tyagi S. Folic acid mitigated cardiac dysfunction by normalizing the levels of tissue inhibitor of metalloproteinase and homocysteine-metabolizing enzymes post-MI. Am J Physiol Heart Circ Physiol 299: H1484H1493, 2010
107. Razani B, Engelman J, Wang X, Schubert W, Zhang X, Marks C, Macaluso F, Russell R, Li M, Pestell R. Caveolin-1 null mice are viable but show evidence of hyperproliferative and vascular abnormalities. $J$ Biol Chem 276: 38121-38138, 2001.

108. Reif A, Frohlich LG, Kotsonis P, Frey A, Bommel HM, Wink DA, Pfleiderer W, Schmidt HH. Tetrahydrobiopterin inhibits monomerization and is consumed during catalysis in neuronal NO synthase. $J$ Biol Chem 274: 24921-24929, 1999.

109. Riad A, Westermann D, Van Linthout S, Mohr Z, Uyulmaz S, Becher P, Rütten H, Wohlfart P, Peters H, Schultheiss H. Enhancement of endothelial nitric oxide synthase production reverses vascular dysfunction and inflammation in the hindlimbs of a rat model of diabetes. Diabetologia 51: 2325-2332, 2008.

110. Sasaki K, Heeschen C, Aicher A, Ziebart T, Honold J, Urbich C, Rossig L, Koehl U, Koyanagi M, Mohamed A. Ex vivo pretreatment of bone marrow mononuclear cells with endothelial NO synthase enhancer AVE9488 enhances their functional activity for cell therapy. Proc Natl Acad Sci USA 103: 14537-14541, 2006.

111. Scatena R, Bottoni P, Martorana GE, Giardina B. Nitric oxide donor drugs: an update on pathophysiology and therapeutic potential. Expert Opin Investig Drugs 14: 835-846, 2005.

112. Schafer A, Fraccarollo D, Widder J, Eigenthaler M, Ertl G, Bauersachs J. Inhibition of platelet activation in rats with severe congestive heart failure by a novel endothelial nitric oxide synthase transcription enhancer. Eur J Heart Fail 11: 336-341, 2009.

113. Schilling K, Opitz N, Wiesenthal A, Oess S, Tikkanen R, MullerEsterl W, Icking A. Translocation of endothelial nitric-oxide synthase involves a ternary complex with caveolin-1 and NOSTRIN. Mol Biol Cell 17: 3870-3880, 2006.

114. Schmidt HH, Nau H, Wittfoht W, Gerlach J, Prescher KE, Klein MM, Niroomand F, Bohme E. Arginine is a physiological precursor of endothelium-derived nitric oxide. Eur J Pharmacol 154: 213-216, 1988.

115. Schmidt T, McNeill E, Douglas G, Crabtree M, Hale A, Khoo J, O'Neill C, Cheng A, Channon K, Alp N. Tetrahydrobiopterin supplementation reduces atherosclerosis and vascular inflammation in apolipoprotein E-knockout mice. Clin Sci (Lond) 119: 131-142, 2010.

116. Schuhmacher S, Schulz E, Oelze M, Konig A, Roegler C, Lange K, Sydow L, Kawamoto T, Wenzel P, Munzel T, Lehmann J, Daiber A. A new class of organic nitrates: investigations on bioactivation, tolerance and cross-tolerance phenomena. Br J Pharmacol 158: 510-520, 2009.

117. Schulman SP, Becker LC, Kass DA, Champion HC, Terrin ML, Forman S, Ernst KV, Kelemen MD, Townsend SN, Capriotti A, Hare JM, Gerstenblith G. L-arginine therapy in acute myocardial infarction: the Vascular Interaction With Age in Myocardial Infarction (VINTAGE MI) randomized clinical trial. JAMA 295: 58-64, 2006.

118. Seerapu H, Subramaniam G, Majumder S, Sinha S, Bisana S, Mahajan S, Kolluru G, Muley A, Siamwala J. Inhibition of dynamin-2 confers endothelial barrier dysfunctions by attenuating nitric oxide production. Cell Biol Int 34: 755-761, 2010.

119. Selemidis $\mathbf{S}$. Suppressing NADPH oxidase-dependent oxidative stress in the vasculature with nitric oxide donors. Clin Exp Pharmacol Physiol 35: 1395-1401, 2008.

120. Shesely EG, Maeda N, Kim HS, Desai KM, Krege JH, Laubach VE, Sherman PA, Sessa WC, Smithies O. Elevated blood pressures in mice lacking endothelial nitric oxide synthase. Proc Natl Acad Sci USA 93: 13176-13181, 1996.

121. Shimokawa H, Tsutsui M. Nitric oxide synthases in the pathogenesis of cardiovascular disease: lessons from genetically modified mice. Pflügers Arch 459: 959-967, 2010.

122. Shiva S, Rassaf T, Patel RP, Gladwin MT. The detection of the nitrite reductase and NO-generating properties of haemoglobin by mitochondrial inhibition. Cardiovasc Res 89: 566-573, 2011.

123. Shiva S, Wang X, Ringwood LA, Xu X, Yuditskaya S, Annavajjhala V, Miyajima H, Hogg N, Harris ZL, Gladwin MT. Ceruloplasmin is a NO oxidase and nitrite synthase that determines endocrine NO homeostasis. Nat Chem Biol 2: 486-493, 2006.

124. Simon A, Plies L, Habermeier A, Martine U, Reining M, Closs EI. Role of neutral amino acid transport and protein breakdown for substrate supply of nitric oxide synthase in human endothelial cells. Circ Res 93: 813-820, 2003.

125. Sowa G, Pypaert M, Sessa W. Distinction between signaling mechanisms in lipid rafts vs. caveolae. Proc Natl Acad Sci USA 98: 1407214077,2001 
126. Stanger O. Physiology of folic acid in health and disease. Curr Drug Metab 3: 211-223, 2002.

127. Stanger O, Fowler B, Piertzik K, Huemer M, Haschke-Becher E, Semmler A, Lorenzl S, Linnebank M. Homocysteine, folate and vitamin B12 in neuropsychiatric diseases: review and treatment recommendations. Expert Rev Neurother 9: 1393-1412, 2009.

128. Stoll S, NejatyJahromy Y, Woodward J, Ozarowski A, Marletta M, Britt R. Nitric oxide synthase stabilizes the tetrahydrobiopterin cofactor radical by controlling its protonation state. J Am Chem Soc 132: 1181223, 2010.

129. Suckling CJ, Gibson CL, Huggan JK, Morthala RR, Clarke B, Kununthur S, Wadsworth RM, Daff S, Papale D. 6-Acetyl-7,7dimethyl-5,6,7,8-tetrahydropterin is an activator of nitric oxide synthases. Bioorg Med Chem Lett 18: 1563-1566, 2008.

130. Sud N, Wiseman D, Black S. Caveolin 1 is required for the activation of endothelial nitric oxide synthase in response to $17 \beta$-estradiol. $\mathrm{Mol}$ Endocrinol 24: 1637-1649, 2010.

131. Suh J, Choi D, Chang H, Cho Y, Youn T, Chae I, Kim K, Kim C, Kim H, Oh B. HMG-CoA reductase inhibitor improves endothelial dysfunction in spontaneous hypertensive rats via down-regulation of caveolin-1 and activation of endothelial nitric oxide synthase. J Korean Med Sci 25: 16-23, 2010.

132. Sun J, Murphy E. Protein S-nitrosylation and cardioprotection. Circ Res 106: 285-296, 2010.

133. Takimoto E, Champion H, Li M, Ren S, Rodriguez E, Tavazzi B, Lazzarino G, Paolocci N, Gabrielson K, Wang Y. Oxidant stress from nitric oxide synthase-3 uncoupling stimulates cardiac pathologic remodeling from chronic pressure load. J Clin Invest 115: 1221-1231, 2005.

134. Tayeh M, Marletta M. Macrophage oxidation of L-arginine to nitric oxide, nitrite, and nitrate. Tetrahydrobiopterin is required as a cofactor. $J$ Biol Chem 264: 19654-19658, 1989.

135. Thum T, Fraccarollo D, Schultheiss M, Froese S, Galuppo P, Widder JD, Tsikas D, Ertl G, Bauersachs J. Endothelial nitric oxide synthase uncoupling impairs endothelial progenitor cell mobilization and function in diabetes. Diabetes 56: 666-674, 2007.

136. Tian J, Hou Y, Lu Q, Wiseman D, Vasconcelos Fonsesca F, Elms S, Fulton D, Black S. A novel role for caveolin-1 in regulating endothelial nitric oxide synthase activation in response to $\mathrm{H}_{2} \mathrm{O}_{2}$ and shear stress. Free Radic Biol Med 49: 159-170, 2010.

137. Tian R, Ingwall J. How does folic acid cure heart attacks? Circulation 117: 1772-1774, 2008.

138. Tiefenbacher CP, Chilian WM, Mitchell M, DeFily DV. Restoration of endothelium-dependent vasodilation after reperfusion injury by tetrahydrobiopterin. Circulation 94: 1423-1429, 1996.

139. Tiravanti E, Samouilov A, Zweier JL. Nitrosyl-heme complexes are formed in the ischemic heart: evidence of nitrite-derived nitric oxide formation, storage, and signaling in post-ischemic tissues. $J$ Biol Chem 279: 11065-11073, 2004.

140. Tiso M, Tejero J, Basu S, Azarov I, Wang X, Simplaceanu V, Frizzell S, Jayaraman T, Geary L, Shapiro C. Human neuroglobin functions as a redox regulated nitrite reductase. J Biol Chem 286: 18277-18289, 2011.

141. Valleggi S, Devaraj S, Dasu M, Jialal I. C-reactive protein adversely alters the protein-protein interaction of the endothelial isoform of nitric oxide synthase. Clin Chem 56: 1345-1348, 2010.

142. van Etten R, de Koning E, Verhaar M, Gaillard C, Rabelink T. Impaired NO-dependent vasodilation in patients with Type II (noninsulin-dependent) diabetes mellitus is restored by acute administration of folate. Diabetologia 45: 1004-1010, 2002.

143. van Haperen R, de Waard M, van Deel E, Mees B, Kutryk M, van Aken T, Hamming J, Grosveld F, Duncker DJ, de Crom R. Reduction of blood pressure, plasma cholesterol, and atherosclerosis by elevated endothelial nitric oxide. J Biol Chem 277: 48803-48807, 2002.

144. Vásquez-Vivar J, Duquaine D, Whitsett J, Kalyanaraman B, Rajagopalan S. Altered tetrahydrobiopterin metabolism in atherosclerosis: implications for use of oxidized tetrahydrobiopterin analogues and thiol antioxidants. Arterioscler Thromb Vasc Biol 22: 1655-1661, 2002.

145. Vásquez-Vivar J, Martásek P, Whitsett J, Joseph J, Kalyanaraman B. The ratio between tetrahydrobiopterin and oxidized tetrahydrobiopterin analogues controls superoxide release from endothelial nitric oxide synthase: an EPR spin trapping study. Biochem J 362: 733-739, 2002.

146. Verhaar M, Wever R, Kastelein J, van Dam T, Koomans H, Rabelink T. 5-Methyltetrahydrofolate, the active form of folic acid, restores endothelial function in familial hypercholesterolemia. Circulation 97: 237-241, 1998.

147. Walter R, Schaffner A, Blau N, Kierat L, Schoedon G. Tetrahydrobiopterin is a secretory product of murine vascular endothelial cells. Biochem Biophys Res Commun 203: 1522-1526, 1994.

148. Werner N, Kosiol S, Schiegl T, Ahlers P, Walenta K, Link A, Böhm M, Nickenig G. Circulating endothelial progenitor cells and cardiovascular outcomes. N Engl J Med 353: 999-1007, 2005.

149. Westermann D, Riad A, Richter U, Jäger S, Savvatis K, Schuchardt M, Bergmann N, Tölle M, Nagorsen D, Gotthardt M. Enhancement of the endothelial NO synthase attenuates experimental diastolic heart failure. Basic Res Cardiol 104: 499-509, 2009.

150. Williams T, Lisanti M. The Caveolin genes: from cell biology to medicine. Ann Med 36: 584-595, 2004.

151. Wilson AM, Harada R, Nair N, Balasubramanian N, Cooke JP. L-arginine supplementation in peripheral arterial disease: no benefit and possible harm. Circulation 116: 188-195, 2007.

152. Wohlfart P, Xu H, Endlich A, Habermeier A, Closs E, Hübschle T, Mang C, Strobel H, Suzuki T, Kleinert H. Antiatherosclerotic effects of small-molecular-weight compounds enhancing endothelial nitric-oxide synthase (eNOS) expression and preventing eNOS uncoupling. $J$ Pharmacol Exp Ther 325: 370-379, 2008.

153. Woo K, Chook P, Lolin Y, Sanderson J, Metreweli C, Celermajer D. Folic acid improves arterial endothelial function in adults with hyperhomocystinemia. J Am Coll Cardiol 34: 2002-2006, 1999.

154. Woodman S, Park D, Cohen A, Cheung M, Chandra M, Shirani J, Tang B, Jelicks L, Kitsis R, Christ G. Caveolin-3 knock-out mice develop a progressive cardiomyopathy and show hyperactivation of the p42/44 MAPK cascade. J Biol Chem 277: 38988-38997, 2002.

155. Xia W, Low P. Folate-targeted therapies for cancer. J Med Chem 53: 66-76, 2010.

156. Xia Y, Dawson VL, Dawson TM, Snyder SH, Zweier JL. Nitric oxide synthase generates superoxide and nitric oxide in arginine-depleted cells leading to peroxynitrite-mediated cellular injury. Proc Natl Acad Sci USA 93: 6770-6774, 1996.

157. Xia Y, Tsai AL, Berka V, Zweier JL. Superoxide generation from endothelial nitric-oxide synthase. A $\mathrm{Ca}^{2+} /$ calmodulin-dependent and tetrahydrobiopterin regulatory process. J Biol Chem 273: 25804-25808, 1998.

158. Xue H, He G, Huang J, Yang Q. New strategy of endothelial protection in cardiac surgery: use of enhancer of endothelial nitric oxide synthase. World J Surg 34: 1461-1469, 2010.

159. Xue H, He G, Wong W, Tian X, Underwood M, Huang Y, Yang Q. Treatment of endothelial dysfunction in hypertension: the role of enhancement of eNOS expression. FASEB J 23: 1017-1021, 2009.

160. Yamashiro S, Noguchi K, Kuniyoshi Y, Koja K, Sakanashi M. Role of tetrahydrobiopterin on ischemia-reperfusion injury in isolated perfused rat hearts. J Card Surg 44: 37-49, 2003.

161. Zhang J, Cai H. netrin-1 prevents ischemia/reperfusion-induced myocardial infarction via a DCC/ERK1/2/eNOS (s1177)/NO/DCC feedforward mechanism. J Mol Cell Cardiol 48: 1060-1070, 2010.

162. Zhang L, Rao F, Zhang K, Khandrika S, Das M, Vaingankar S, Bao X, Rana B, Smith D, Wessel J. Discovery of common human genetic variants of GTP cyclohydrolase 1 (GCH1) governing nitric oxide, autonomic activity, and cardiovascular risk. J Clin Invest 117: 2658-2671, 2007.

163. Zhao Y, Liu Y, Stan R, Fan L, Gu Y, Dalton N, Chu P, Peterson K, Ross J, Chien K. Defects in caveolin-1 cause dilated cardiomyopathy and pulmonary hypertension in knockout mice. Proc Natl Acad Sci USA 99: 11375-11380, 2002.

164. Zhao Y, Zhao Y, Mirza M, Huang J, Potula H, Vogel S, Brovkovych V, Yuan J, Wharton J, Malik A. Persistent eNOS activation secondary to caveolin-1 deficiency induces pulmonary hypertension in mice and humans through PKG nitration. J Clin Invest 119, 2009-2018, 2009.

165. Zimmermann K, Opitz N, Dedio J, Renné C, Müller-Esterl W, Oess S. NOSTRIN: a protein modulating nitric oxide release and subcellular distribution of endothelial nitric oxide synthase. Proc Natl Acad Sci USA 99: 17167-17172, 2002.

166. Zweier JL, Li H, Samouilov A, Liu X. Mechanisms of nitrite reduction to nitric oxide in the heart and vessel wall. Nitric Oxide 22: 83-90, 2010.

167. Zweier JL, Wang P, Samouilov A, Kuppusamy P. Enzyme-independent formation of nitric oxide in biological tissues. Nat Med 1: 804-809, 1995. 